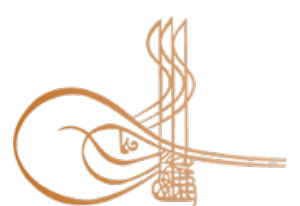

www.turkishstudies.net/economy
Turkish Studies - Economics, Finance, Politics

eISSN: $2667-5625$

Research Article / Araştırma Makalesi

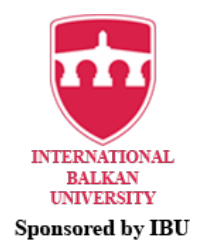

Sponsored by IBU

\title{
Yunus Emre Aslında Ne Dedi?
}

What Did Yunus Emre Actually Say?

\author{
Kenan Göçer*
}

\begin{abstract}
The study reconsiders the distribution of capital or accumulation by Yunus Emre, not from the religious, mystical, philosophical, literary and historical point of view as it has been done so far, but from the perspective of political economy. Islamic sufism has always been more influential than the madrasa in transforming and affecting the society throughout history generally in muslim societies, particularly in Turkey. In some geographies and times, it has succeeded to be the most tolerant institution or movement having varied appearances against the other. The most prominent movements of mysticism in influencing Anatolia during the Seljuk and Ottoman periods were sufism, traveling dervishness like qalanderiyya and the melami mystics. These Sufi movements can be compared in some ways to schools such as Epicurism, Cynicism, and Stoicism in ancient philosophy. Yunus Emre as a Melami is distinguished from sufis and traveling dervishes in many ways and marked as most known unifying character of social culture of Turks. The most fundamental element of his distinction in terms of political economy is trying to level or distribute accumulation in every field although he gives importance to work, profession and labor. In this sense, Yunus's attempt is compared to the isonomic principle, which Kojin Karatani claims existing in Ionia of ancient times, which means that the absence of a ruler and ruled and the possibility of freedom and equality at the same time. The isonomic distribution is carried out in five ways within the framework of self, property, meaning or logics, prestige or reputation and linguistic distance. Moreover, Miskinlik that is one of the basic concepts of Yunus is subjected to a new reading outside of common perception.
\end{abstract}

Structured Abstract: This study, which aims to analyze Yunus Emre in terms of political economy while other studies related to the topic have done from the point of view of Sufism, literature and history, is opened within the framework of the isonomic principle that Kojin Karatani believes to exist in Ionia. Isonomia means that freedom and equality exist simultaneously. The simultaneous existence of freedom and equality also means to eliminate the distinction between the ruler and the ruled. In this respect, the article is not a study of sufism, history, literature, history of economics or history of philosophy, but it aims to address Yunus' political economy, which has never been addressed.

Since general belief is considered within the history and literature of Sufism, it tends to see Yunus in "people's Islam" or Sufi. What Yunus says or his stance will not be understood, unless Yunus is positioned correctly. It is beneficial to subject Sufistic movements to a certain distinction in terms of affecting Anatolia and Yunus, the first step of understanding or being understood more accurately. Although the Sufistic

\footnotetext{
* Doç. Dr., Sakarya Uygulamalı Bilimler Üniversitesi, Uygulamalı Bilimler Fakültesi, Uluslararası Ticaret ve Lojistik Bölümü.

Associate Professor, Sakarya University of Applied Sciences, Fakulty of Applied Sciences, International Trade and Logistics.

ORCID 0000-0003-4947-0399

kenangocer@subu.edu.tr

Cite as/ Atıf: Göçer, K. (2020). Yunus Emre Aslında Ne Dedi?. Turkish Studies - Economy, 15(2), 817-842.

https://dx.doi.org/10.29228/TurkishStudies.41895

Received/Geliş: 03 February/Şubat 2020

Accepted/Kabul: 20 June/Haziran 2020

Copyright (C) INTAC LTD, Turkey

Checked by plagiarism software

Published/Yaym: 25 June/Haziran 2020

CC BY-NC 4.0
} 
movements do not differ sharply from each other, there are still distinct differences between them. These categories are; Baghdad centered Sufism, calender's type of traveling dervishness and Khorasan-Nishapur originated mellami mystics. In this study, Yunus is evaluated within the Anatolian Melami, which is the extension of Khorasan-Nishapur originated melami mystics. As it is known, melamism is the condemnation, cursing, criticism or self-criticism of the nafs.

The reason for the criticism was the extreme sensitivity to the nafs. If the nafs is not under control; he fell out of sincerity and violation by either falling into self-liking, pretending, or hypocrisy. Ihlas meant that the soul, whose desires were motivated, was kept under constant surveillance. In other words, this was possible by criticizing oneself or by keeping the self under blame or control. They gave importance to having a profession in the society without showing off or attracting attention. In this sense, they were separated from the traveling dervishes and Sufis. Melamis were neither sufis nor dervishes in terms of appearance. They did not even have any style or shape to show themselves.

Sufis thought that they would reach happiness by trying to keep themselves away from everything, including mind, except the friendship between the creator and the creature (wali-awliya) and love. They had neutral attitudes about having a job and a family. They did not have any rhetoric against power, and it can even be said that they exhibited a passive situation. In this sense, they did not pose a political threat. However, not all of them were apolitical or the features mentioned were not seen in all Sufis. Rulers did not want to see the Sufis and the wide disciples against them even if they could not see them their side. They did not have a problem to appear in front of political elites. Although they did not have a job, they did not have a clear attitude towards not having a family. In this way, they seemed to pursue an individual spiritual pleasure rather than a material pleasure.

As for the traveling dervishes, they refused society because they did not recognize any social rules. They had neither families nor jobs. They were also against marriage. They had an almost opposite position of the Sufis. They were begging as a community all year round and eventually retreating to their dervish lodge. They rejected all kinds of accumulation, hierarchy and society. They were even against working. It was stated that they lived like animals.

If roughly associated with philosophical thoughts; Sufis are like non-materialistic epicurean, or Sufispiritual hedonist, travelling dervishes, are like non-individual kinics, although it is not a philosophical typology, it can be used only for ease of analogy, Mellamis can be compared to stoics who have a profession. However, Yunus, whose social place is in the black budun (people), cannot be a complete stoic because he has a profession (nomadic and / or farmer). While the stoics who live according to their principles and do not think about the result-reward, take an elitist stance, the Christian saint is the monastery employee who aims to convey the knowledge of the stoics to the public. In this sense, Yunus, on the one hand, is a mixture of stoic wise and saint, on the other hand it looks like the synthesis or between the Sufi and the traveling dervish. This mediocre form of him appears more clearly in his view of things, people, profession and God: He is in the middle of everything and wants to keep this attitude in everything.

He sees all structures that remain outside the average as accumulation and wants to distribute and level them until they find their average. Any accumulation that is not distributed includes discrimination and creates debt. Discrimination and debt contain fear or violence. There is no freedom where there is fear and violence. He seems to want to achieve both freedom and equality by distributing the accumulation. According to Yunus, accumulation is not just material. It occurred in five aspects and this should be distributed: Self, materiality, meaning-logic, status-reputation and language.

He starts from the name of distributing the self. The aim is to distribute the self and ensure that everyone meets on their own. Secondly, he distributes with the property through criticism it has made to the love of property. If we evaluate the language as an accumulation of meaning-logic, he tries to distribute the meaning or logic in his famous poem that started with "I climbed to the plum branch, I ate the grape". It continues to distribute with status and reputation. While self is the imaginary accumulation of the person, reputation is the social accumulation of the self. He does not hesitate to use his language against all kinds of status holders. The existence of the ruling and ruled separation itself is already an accumulation of reputation. Dissemination of this accumulation is an attitude towards this distinction. In the end, he avoids using the "foreign" (Persian) language that the ruler (ak budun) cares and uses. What he does is the distribution of this linguistic distance-separation against society.

Turkish Studies - Economy, 15(2) 
Yunus foresees distribution of distance to eliminate discrimination. Equality and freedom are achieved as a result of the distribution of accumulation or discrimination. The establishment of equality and freedom is the establishment of the mediocre or the enlargement of it. To understand all this distribution, central concepts in Yunus need to be understood. At the beginning of this is the concept of miskin. According to Yunus, the miskin is not lazy and idle, although he or she works and has a profession, he is not accumulating. Yunus did this with his life, but he paid for it by being made his traces forget.

Keywords: History of Economics Thought, Yunus Emre, Kojin Karatani, İsonomia, Political Economy, Sufi, Traveling Dervish, Accumulation, Melami.

Öz: Çalışma, bugüne kadar yapıldığı üzere Yunus Emre'yi dinî, tasavvufî̀, felsefî, edebî ve tarihî açıdan değil, ekonomi politik bir bakış açısıyla birikim veya sermaye dağıtımını ele alıyor. Genel olarak İslam toplumunda, özel olarak da Türkiye'de tasavvuf, tarih boyunca toplumu etkilemede ve dönüştürmede medreseden her zaman daha etkili bir olgu olmuştur. Kimi coğrafyalarda ve tarihlerde farklı görünümlere bürünerek 'öteki'ne en tahammüllü kurum veya hareket olabilmeyi başarmıştır. Selçuklu ve Osmanlı döneminde Anadolu'yu etkilemede en etkin tasavvuf hareketleri sûfîlik, gezgin dervişlik (kalenderîlik vs.) ve melâmetîlik - melâmîlik olmuştur. Bu tasavvuf hareketleri bazı yönlerden ilkçağ felsefesindeki epikürist, kinik ve stoacılar gibi akımlara benzetilebilir. Bir Melâmî olarak Yunus Emre, sûfîlerden ve gezgin dervişlerden pek çok yönlerden ayrılarak Türklerin toplumsal kültürünün en çok anılan birleştirici karakteri olarak belirginlik kazanır. Ekonomi politik açıdan belirginliğin en temel unsuru çalışma, meslek ve emeğe önem vermesine rağmen birikimi her alanda tesviye etmeye ya da dağıtmaya çalışmasıdır. Bu anlamda Yunus'un girişimi, Kojin Karatani'nin antik dönem İyonya'sında var olduğunu iddia ettiği gibi yöneten ve yönetilenin olmayışı, özgürlük ve eşitliğin aynı anda mümkün oluşu demek olan izonomik ilkeye benzetilmiştir. Söz konusu izonomik dağıtım; benlik, mülk, anlam - mantık, statü - itibar ve dilsel mesafe çerçevesinde olmak üzere beş yönden gerçekleştirilmiştir. Yunus'ta merkezi kavramlardan olan miskinlik de yaygın algının dışında yeni bir okumaya tabi tutulmuştur.

Anahtar Kelimeler: İktisadi Düşünce Tarihi, Yunus Emre, Kojin Karatani, İzonomi, Ekonomi Politik, Sufi, Gezgin Derviş, Birikim, Melami.

\section{Giriş}

Tasavvuf, İslam tarihi boyunca insana ulaşmada, onda bir duygulanma oluşturmada İslam kültürünün diğer unsurlarından her zaman daha etkin olduğu söylenebilir. Türklerin gerek Müslümanlaşma sürecinde ve gerekse sonrasında mutasavvıflar gündelik hayata, siyasete ve ekonomiye rengini katabilmiştir. O renklerin önemli göstergelerinden olan, 'eren-ermiş' ve 'dost' anlamındaki veli, evliya ve velayet gibi terimler ilgili literatürde ve gündelik hayatta hâlen yaşadığı gibi ad olarak aynı kökenden gelen ve ilin merkezî yönetim temsilcisi olan vali (seven, dost) unvanı da (Devellioğlu, 1996: 1136, 1146) yine bugün Türk idare sisteminde önemli bir makamı temsil etmeye devam ediyor.

Buna karşın Türkiye'de ilden daha küçük ilçe adına da yakın zamana kadar kaza deniliyordu. Bir yargı bölgesi olan kaza adı, Osmanlı'da medrese kökenli bir $k a d l$ tarafindan yönetiliyordu. Fakat bugün modern Türkiye'de medrese kökenli kadı (yargıç-yönetici) ve kaza (ilçe) adı resmî olarak yaşamazken, veli-evliya-velayet gibi tasavvuf literatürünün önemli terimleriyle yakınlığı olan vali, ili resmen yönetmeye devam etmektedir.

Toplumla iç içe olan tasavvufun medreseden daha uzun dönemli (long duree) etkisi âşıkmiskin Yunus Emre'den de izlenebilir. Türkiye kültür tarihinde ismi tartışmasız en derin etki bırakan kişilerin başında Yunus Emre gelir. Etki sadece Türkiye'de değil, aynı zamanda Türkçede ve Türklerin tinsel ikliminde de varlığını duyurur. Bu anlamda Yunus Emre, Türklerin varlığını doyurmayı ve duyurmayı sürdürmektedir.

Türkiye, Türkler ve Türkçe üzerinde ve içinde, kurucu bir etkiye sahip Yunus Emre'nin bugüne kadar çoğunlukla tarihi, dini-tasavvufi, felsefi ve edebi yanı üzerinde duruldu. Söz konusu 
alanda yapılan çalışmalara ekleme yapmak ve bakış açısı anlamında bir yenilik getirmek bu çalışmanın amaçları dışındadır. Amacım, Yunus Emre'nin ekonomi politik bir yanının da olduğunu ortaya koymaktır. Hatta bu ekonomi politik yanın diğer alanlardan ayrışamazlığının da altını çiziyorum. Bunu yaparken ihtiyaç duyuldukça tarihi, dini-tasavvufi, felsefi ve edebi çalışmalardan da elbette faydalanılacaktır. Zaten biraz da o alanlardaki çalışmaların varlığı, burada yapılmaya çalışılanı mümkün kılmıyor mu?

Sözü getirmek istediğim yer şurasıdır: Yunus Emre’yi, Kojin Karatani'nin İzonomi ve Felsefenin Kökenleri (2018) adlı kitabındaki izonomi ilkesi/tezi üzerinden okumaya çalışacağım. Kitap, her ne kadar felsefenin hem coğrafya hem de kavramsal kökende bir merkez kaymasına yol açmasını önerse de, felsefenin hayatla içiçeliğini politik ve ekonomik gerçeklik çerçevesinde anlatması açısından yeni bir bakış açısı sunuyor. Bu açıdan İzonomi, öne çıkardığı teziyle felsefenin sadece Atina merkezîliğini sarsmış olmuyor, aynı zamanda onun politika ve ekonomi ile ayrılmaz bağını da kurmuş oluyor.

Yakın zamanda yayımlanmış eserinde Karatani, hükmetmenin olmaması demek olan izonomiyi (íoovouía-isonomia. İsos: eşit; nomos: hukuk, adet), MÖ. 6. yüzyıl civarında İyonya'da "yalnızca bir fikir değil, yaşanan bir gerçeklik" olarak görür. Karatani (2018: 28-29), Herodotos'un Tarih'inde izonomi kavramının geçtiğini ve fakat bunun demokrasi ile karıştıııldığını, ancak Hannah Arendt'in (2012: 38-39) bu ikisini ayıran tek kişi olduğunu söyleyerek Atina'daki demokrasinin kökenini İyonya'daki izonomiye bağlar.

İzonomi, sadece yöneten ve yönetilen ayrımının olmaması değil, aynı zamanda özgürlük ve ekonomik eşitliğin de sağlanması anlamına gelirken, "demokrasi, çoğunluğun hükmetmesi" (Karatani, 2018: 31) olduğu için kavram veya olguların birbirine zıtllğı kendiliğinden ortaya çıkmış olur. Zitlıkları vurgulamaya devam ettiğimizde; Atina demokrasisi kölelerin ve yabancıların sömürüsüne dayanırken, İyonya izonomisi köle ve yabanc1 ayırt etmeksizin herkesin özgür ve ekonomik eşittiğine dayanıyordu. Kısaca izonomi, hiç kimsenin hiç kimse üzerinde hakimiyet kuramadığı, polis (şehir) içinde herkesin kendi toprağını işleyecek büyüklükte bir işletmeye sahip olduğu, kimsenin bu sebeple köleleştirilemediği bir düzendir.

Bu sebeple İyonya'daki insanlar birbirlerinden daha birikimli değildi ve istese de olamıyordu. Birikim konusunda birbirlerine eşdeğer bir konumda oldukları anlamına geliyor bu. İyonyalılar bir köle veya yabancı çalıştırmaya kalktıklarında köle ve yabancılar, civardaki boş ve sahipsiz tarlalara gidip o tarlaları işlemeye başlayabiliyorlardı. Atinalıların aksine İyonyalılar köle çalıştıramadıkları için herkes kendi toprağını işliyor ya da işlemek zorunda kalıyordu. Köleye sahip olmadan bir ailenin işleyebileceği toprak biriminin de doğal olarak bir sınırı olmalıydı. İşte herkes o sinıra sahipti. Ekonomik olarak herkesin neredeyse eşit, birikim yapamayacak ölçüde bir geçimliği vard. $\mathrm{Bu}$ durum, kimsenin kimse üzerinde hakimiyet kuramamasına neden oluyordu. Hakimiyet kurulamamasının diğer bir nedeni de kendi şehirlerini koruyacak ayrı bir askeri sınıfın olmamasıydı. Zaten askeri sınıfının olmaması, savaş esnasında şehirdeki her vatandaşın kendi kendini koruması sonucunu zorunlu kılıyordu. Ayrı bir askerî sınıfın olmaması ise sonradan Persler tarafından İyonya şehirlerinin işgalinin sebebi olacaktı.

İyonya polis-şehirlerindeki vatandaşların özgürlüğü nereden geliyor sorusuna, Karatani’nin cevabı açıktır. Yunan anakarasında savaşlarda yenilgiye uğrayan halkın koloniler şeklinde başta Ege kıyıları ve diğer kıyı bölgelere göç etmesi sonucunda kurulan küçük polislerde (Efes, Milet, vs.) pazar ekonomisinin oluştuğu, paranın ortaya çıktığı, halkın ticaret ve üretimle uğraştığı, büyük ailelerin etkisinin geride (Yunan anakarası) kaldığı bir şehir konseyinin varlığı özgürlük olarak değerlendiriliyor (2018: 41-43). Büyük ailelerin etkisinin geride kalması demek, İyonya polislerinde büyük kabileler yerine herkesten biri olarak bireyin ortaya çıkması ve onun özgürce konuşması anlamına geliyordu. 
Söz konusu izonomik ilkenin Yunus Emre'nin kendisinde mi, yoksa döneminde mi ortaya çıkmış olduğu sorusunu bu çalışmada Yunus'un kendisi üzerinden cevap aranacaktır. Bunu yaparken de kendi metni olduğunu varsaydığımız ve Mustafa Tatçı'nın hazırladığı Yûnus Emre Divânı'nı (2005 ve 2016) ve Risâletü'n-Nushiyye'sini (2005) esas alacak, ihtiyaç halinde elbette başka çalışmalardan da faydalanılacaktır. Yinelemek ve kısaca belirtmek gerekirse Yunus'un birikimi dağıtmaya çalıştığ ortaya konacaktır. Söz konusu dağıtma sebebinin İslam'ın “Onlar, karşılıksız temizleyici harcamada bulunurlar." emri gereği (Kur'an, 23:4) olduğu kadar kendi toplumsal biçimlenmesiyle de ilgili olduğu görülecektir. Ama öncelikle Yunus'un tarihsel konumunun hangi tasavvufî uğrağa karşılık geldiğinin ortaya konması gerekecektir.

\section{Anadolu Melamiliği, Tasavvufun Orta Yolu Mu?}

Bir tasavvuf tarihi olarak değerlendirilmemesi gereken çalışmanın bu kısmında, Yunus Emre'nin tasavvufî yönelimi genel hatlarıyla belirtilmeye çalışlacaktır. Ekonomi politik bir tema üzerinden bu hatları genel olarak sıraladı̆̆ımızda;

a) Bağdat çevresi, Endülüs ve Orta Asya'ya kadar uzanan Bağdat sûfiliği,

b) Gezgin dervişlik (Kalenderi ve Haydarilik) ve

c) Horasan-Nişabur melâmetîliği - melâmîliği

bu hatlar arasında sayılabilir.

Söz konusu ayrımlar elbette ne o kadar sert ne de kendi içinde o kadar homojen bir yapıdadır. Birbirileri arasında yer değiştirmeler olduğu gibi, tarih içinde de bazı değişiklikler ve gelişmelerin olmas1 neticesinde ilk hallerini tamamen koruyabildikleri söylenemez. Hatta bu ayrım bütün tasavvufi akımları da içermez. Çünkü hem ekonomi politik açıdan ihmal edilebilir olanlar, hem de Yunus Emre veya Anadolu'ya etkisi ulaşmadığı varsayılanlar genel sıralamaya dahil edilmemiştir.

Öyleyse Yunus'u burada hangi akım içinde değerlendirmeliyiz? Horasan-Nişabur melâmetîliğinin Anadolu melâmîliğine uzanan kolu içinde görmek daha doğru görünüyor. Ancak bu akımların öncelikle önde gelenlerinin ve genel özelliklerinin ortaya konmasında fayda var. Genel özelliklerini, daha çok benzeşen yanları üzerinden değil, ayrışan özellikleri ortaya konarak ilerlendiğinde çalışmanın amacına uyulmuş olacaktır.

Tasavvufun, İslam tarihinin seyri içinde Arap olmayan Müslümanların sosyo ekonomik ve siyasi rahatsızlıklarından kaynaklı Arap asabiyesine karşı kültürel bir tepki olarak ortaya çıktığı genellikle kabul gören bir görüştür (Ocak, 1992: 3). En erken tasavvufî̀ yaklaşım veya tepki olan sûfîlik ise 8. yüzyıl sonu ile 10. yüzyıl başı arasında zâhidane bir dindarlık olarak Bağdat'ta doğmuştu. Aynı zamanlarda Bağdat'ın güneyinde, İran'ın kuzeydoğusunda ve Orta Asya'da, sonradan Bağdatlı sûfîlerle kaynaşacak olsalar da farklı biçimlerde sûfiler ortaya çıktı (Karamustafa, 2017: 3). Bağdat sûfîleri olarak ifade edilen bu akım, sınıflandırmamızın birinci kısmını oluşturuyor.

Bağdat sûfîlerinden bazılarınını şu şekilde sıralayabiliriz: İbrahim b. Edhem el-Belhî (ö.778?), Hasan el-Basrî (ö.728), Bişr el-Hafî (ö.841), Basralı Râbia el-Adeviyye (ö.801?), Zünnûn el-Misrî (ö.859?), Horasanlı Bâyezid-i Bistâmî (ö.848?), Ebû Saîd el-Harrâz (ö.890?), Cüneyd-i Bağdâdî (ö. 909) ve Hallâc-1 Mansûr (ö.922). Bu isimlere şüphesiz daha başka sûfiler de eklenebilir.

Ahmet T. Karamustafa Tasavvufun Oluşumu'nda Bağdat sûfîlerinin öne çıkan özelliklerini belirtir. Bu özellikler arasında ilk sûfîlerin en çok tevhid üzerinde durarak keşif ve deneyime dayalı bir bilgi elde etmek istediklerini (2017: 31), Allah ile yakınlaşma ve dostluk kurabilmek için onun tarafından seçilmiş olanların (ayrıcalıklı seçkin, havass) Allah dostu (veli, ç. evliyâ) olabileceğini ve bu sebeple sıradan Müslümanlardan (âvâmm) farklı ve ayrı olarak kabul edilmelerinin arzulanmış olduğunu ifade eder (2017: 33). Kur'an ve Hadis gibi alanlarda da bilgili olan Bağdat sûfîleri son derece yüksek bir entelektüel çevre oluşturdular. Ancak aklı kullanmaya karşı kuşkularından dolayı kelam, fikıh ve edebiyat gibi alanlara karşı ya şüpheci ya da en azından uzak durmaya çalıştılar. Keşif 
ve deneyimci sûfîler kelam ve fikıh usûlü gibi alanlara mesafeli olmaları yanında, deneyime önem vermelerine rağmen hukukun bizzat uygulamasını yürüten mesleklere (fâkih) karşı da mesafeli olmuşlardır (2017: 34).

Bağdat sûfîlerinin çoğunluğu, Kalenderî ve Haydarî gezgin dervişler gibi dilenci olmadılar. Öyle görünüyor ki sûfîler, yaratıcı ile yaratılan arasındaki samimi ilişki, dostluk ve aşk dışında akıl dahil her şeyden kendilerini uzak tutmaya çalışarak mutluluğa ulaşacaklarını düşünüyorlardı. Bu sebeple akılcı mezhep Mutezile'ye karşı da aynı mesafeyi korudular. İş ve aile sahibi olmak konusunda da tarafsız tutumlarını sürdürdüler. Yine aynı mesafeyi bir orta sınıf kentlisi olarak sosyal ve politik alan için de yaptılar. İktidara karşı herhangi bir söylemleri yoktu ve hatta pasif bir tutum sergiliyorlardı. Bu anlamda politik bir tehdit oluşturmadılar. Ancak hepsi apolitik değildi veya belirtilen özellikler bütün sûfîlerde görülmüyordu. Örneğin Hallâc-1 Mansûr, hayatını kaybetmesine neden olsa da sonradan sosyal ve politik bir eylemciye dönüşebilmişti (Karamustafa, 2017: 39-40).

Zaten birkaç yüzyıl sonraki zamanda popülerliği artıp halk entelektüelleri olarak görülmeye başlanmasıyla sûfîler, politik çevrelerce şehrin dikkate alınacak bir kesimi olarak kabul edildi. Yönetimi ele geçiren kesimler, sûfîleri ve etrafindaki geniş mürid çevresini yanlarında göremese bile karşılarında görmek istemiyordu. Onların da politik çevrelerin karşılarında görünmek gibi bir meselesi yoktu zaten. İş ve aile sahibi olmama tercihi radikal bir yoksulluğun varacağ yalnız bir yaşamdı. Bu haliyle maddi hazzın aksine bireysel bir manevi hazzın peşindeymiş gibi görünüm arz ediyorlard.

Ancak zühdün ilk ortaya çıktığı Hicaz gibi yerlerde "pasif bir tepki” olarak görülen sûfîlik, en başta konformist (uyumcu) olmayan bir özellik taşıyordu. Toplumsal bilinirliği arttıkça seçkin bir insan (havass, Allah dostu, velî) olma yolunda karizmatik bir kimlik kazanarak siyasal otoritelerin de meşrulaştırılmasında büyük bir işlev gördüler ve sonraki zamanlarda "konformist" bir tavrın egemenliği altına girdiler (Ocak, 2011a: 71-75). Sûfîleri 'bireysel bir manevi hazzın peşindeymiş gibi’ nitelerken kastedilenin söz konusu konformist tavır olduğu belirtilmelidir.

İkinci tasavvuf akımı olarak Kalenderîler ve Haydârîler adlı gezgin dervişleri sayabiliriz. Bağdat kökenli ilk sûfî hareketten iki üç yüzyıl sonra (1200-1500) yeni bir zahitlik türü olarak İranSuriye ve Mısır'da gezgin dervişler göründü. Anadolu, Suriye ve İran batısında görülen Barak Baba (ö.1307-8), İran kökenli Cemâleddin-i Sâvî'nin (ö.1232-33) kurduğu Kalenderîlik ile yine İran Türklerinden olduğu ifade edilen Zâveli Kutbeddin Haydar'ın (ö.1221?) (Yazıc1, 1998: 17/25) takipçilerince kurulan Haydârîlik adlı her iki hareket de hızla Anadolu ve Hindistan'a yayıldı. Ancak kalenderin Hindistan çevresi dillerde de bir karşı1lı̆̆ zaten vardı (Karamustafa, 2019: 43). Arapçada "dilenci derviş", Farsçada "kaba sırık, kaba; yontulmamış adam" anlamına gelen qalandar/Kalender (2019: 42), tipoloji olarak İran edebiyatında 11. yüzyıl sonlarında aslında çokça biliniyordu (2019: 43). Gerek Kalenderîler ve gerekse Haydârîler, Bağdat kökenli ve yalnız yaşama arzusuna bağlı sûfîlerden farklı olarak yine bir zühd hareketi olan İran Kerrâmîliğinin geliştirdiği 'tekke'yi de (hânkâh) yöntemlerine dahil ederek toplu gezgin derviş yaşamını benimsediler. Tekke / hânkâh, mevsimin bir döneminde topluca gezip dilendikten sonra geldikleri yerdi.

Haydârîler sakal kesip bıyık uzatırken (Yazıcı, 1998: 17/25), Kalenderîler pek çok gezgin dervişler gibi dört vuruş (çahâr darb) denilen dörtlü traşa uyarak saç, sakal, bıyık ve kaşlarını kesiyorlard1 (Azamat, 2001: 24/253). Bunun toplumsal bir itibar kayb1 veya itibara itibar etmeme olduğu aşikâr. Diğer taraftan bu, hareketin topluma karşı duruşunun sadece bir dış ifadesiydi. Karş1 duruş bununla sınırlı değildi. Başta şeriat (farzlar) ve toplumsal düzenin kendisine olmak üzere, buna uzlaşmaz bir kural karşıtlı̆̆ kaçarak değil, aksine bu karşıtlığı adeta toplumun gözünün içine sokarcasına aktif bir eylem olarak "toplumun Tanrıya ulaşma başarısızlığını ayıltıcı bir biçimde eleştirmek amacında olduğu için kendisine toplumun kalbinde 'toplumsal bir vahşilik' yaratıyordu” (Karamustafa, 2019: 23). Çünkü gezgin dervişe göre toplumsal yaşam, insanların Tanrı'ya ulaşmasını engelliyordu (2019: 23). 
Toplum ile yasa arasında fark gözetmiyorlar, yasa veya topluma katlanmaktansa hayvan gibi yaşamayı tercih ediyorlardı. Ancak hayvanları da bir yasa içinde görürler, çünkü çiftleştiklerinde onlar da çoğaldıkları (fazlalık, artı değer, artık) için Kalenderiler, sonu çoğalmaya/doğurmaya varan çiftleşmekten de (cinsellik) uzak duruyorlardı. Bu anlamda gerek Selçuklu'da ve gerekse Osmanlı'da bütün düzen bozan hareketlerde bu tiplere "başıbozuk" denecektir (Sayın, 2018: 25).

Mal-mülk sahipliği veya edinimin en aza indirilmesi, itibara mesafe, beden sağllğı ve çocuk sahibi olma gibi cinsel üretimin reddinin gezgin dervişliğin en belirgin özellikleri olduğu söylenebilir. Otman Baba, Kutbeddin Haydar, Cemâleddin-i Sâvî ve Rum Abdallarının uzun dönem hiç giysi giymedikleri biliniyor. Otman Baba, Kutbeddin Haydar ve Cemâleddin-i Sâvî geçim için doğaya yönelmiş, başkalarının vereceği mal ve paradan özenle uzak durmuş ve her türden yardımı da kesin olarak geri çevirmişlerdi (Karamustafa, 2019: 24). Sonradan takipçileri için bu kural daha da yumuşamış ve hatta iptal edilmiş görünüyor. Gezgin oldukları için ne aileleri ne de belirli bir ikametleri vardı. Doğal olarak işleri de yoktu. Çoğunluğu kazançlı işe hor bakıyor, geçim için başkalarının yardımına muhtaç oluyorlardı. Ne yaparsa yapsınlar yaptıkları her işte dikkate aldıkları konumlanma, toplumla çelişme veya ona yönelik karşıtlı̆̆ın aktif olarak vurgulanması esasına dayaniyordu (Karamustafa, 2019: 28).

Toplum karşısında ölmeden önce ölen (el-Acluni, 2019: 2:29) gezgin dervişler, yasal yaptırımları hiçbir şekilde ciddiye almıyorlardı. Bu da toplumsal yapıyı her yönden reddettikleri anlamını taşıyordu ki, bu yönüyle Kiniklere (kyon: köpek; kynik: köpeksi) benzetilebilir (Gökberk, 1996: 52; Ocak, 1992: 69-70; Gölpınarl1, 1992: 18). Bilindiği üzere Kinikler dilenci hayatı sürüyor, çalışmayı, birikimi, hiyerarşiyi ve ünü reddediyorlardı (Cevizci, 2014: 173). Bunu yapmaktaki amaçları mutluluğun "dış dünyada değil, insanın kendisinde" olduğuna inanmalarıydı. Bu da dış dünyaya ve onun her türden nimetlerine karşı kayıtsızlığı gerektiriyordu (Arslan, 2018: 338). Ancak tarihsel ve dinî bağlam farkını saymazsak gezgin dervişlerin Kiniklerden belirgin farkı, dervişler toplu olarak dilenip sonunda tekkelerine çekilirken; Sinoplu Diyojen (Diogenes) örneğinde olduğu gibi Kinik, bunu tek başına yapıyordu. Her iki yaşam tarzının nihai amacı toplumu da (-hiyerarşiyi) bir çeşit birikim olarak görüyor olmalarıydı.

Birikim veya topluma karşı son derece aşağılayıcı tavrın kökeninde kendilik bilincine, kendini tanımaya, özgürlüğe, özgür ifadeye ve hakikate yönelik aşırı düşkünlük söz konusudur. Birikimin aynı zamanda bir yük de olduğunu düşünürsek, dış dünyanın yüklerinden kurtuldukça Kinik/Derviş hakikate ulaşabilecek ve doğruyu cesaretle söyleyebilecektir -parrhessia- (Foucault, 2016). İktidar ve toplum tarafından politik bir tehdit olarak görülmese de iyeliğin yeniden düşünülmesini îma eden yanı dolayısıyla içsel bir tartışmanın bitmeyecek bir çağrısı gibi durur göz önünde. Kendine yettiği (otarşi, autarkeia) ölçüde kişinin başkasına bağımlılığı azalacak ve hakikati korkmadan ifade (parrhessia) edebilecek bir eylem özgürlügüne (eleutheria) ulaşacaktır (Cevizci, 2014: 173). Derviş ve Kiniklerin bu özgürlüğe ulaşmasının yolu ise ancak yüklerinden (her anlamda birikim, sermaye, kapital, töre, mantık; dil olarak mana-anlam; toplumsal düzen olarak hukuk veya toplumun bizatihi kendisi) kurtulmakla olacaktı. Böylelikle eylem ve inanç-düşünce birlikteliğine (mümin), yani bir çeşit gerçek birliğe varılmış olunuyordu ki, bu da hakikatin biricikliğinin ayrı bir ifadesidir.

Üçüncü ve son akım olarak da Anadolu melâmîliğine uzanan Horasan-Nişâbur melâmetîliğini sayabiliriz. Melâmetîlik (melâmet: lanetleme, kınama, ayıplama), daha çok Nişâbur'da olmak üzere Horasan çevresindeki Nişâburlu Ebû Hafs Amr b. Seleme el-Haddâd (ö.874) (Yazıc1, 1994: 10/127-128) ve Melâmetiyye akımının ilk temsilcisi olan yine Hamdûn Kassâr olarak bilinen Nişâburlu Ebû Sâlih Hamdûn b. Ahmed b. Umâre (ö.884) (Kara, 1997: 15/455-456) gibi insanların başını çektiği bir tasavvuf akımıdır.

Akımın en önemli özelliği nefse karşı aşırı hassasiyetti. Bağdat sûfîleri gözünü veya gönlünü Allah'a ulaşmaya dikmişken, melâmetîler aynı dikkati nefse vermişlerdi. Gözetim altında 
tutulmadığında nefs, ya kendini beğenmeye $(u c b)$, ya rol yapmaya (iddia), ya da ikiyüzlülüğe (riya) düşüp samimiyetten (Karamustafa, 2017: 62; Çakmaktaş, 2017: 358), "ibadet ve iyilikleri riyadan ve çıkar kaygılarından arındırıp sadece Allah için yapmak" demek olan ihlâstan (Ateş, 2000: 21/535) uzaklaşmaktaydı. İhlâslı olmak, arzuları güdüleyen nefsin sürekli kontrol altında tutulması demekti. Bir başka ifadeyle bu, kendini eleştirmekle yani nefsi melâmet ya da gözetim-töhmet altında tutmakla mümkündü. Gösterişe (riya) düşmeden ya da dikkat çekmeden toplumun [âvâm, halk, kara budun] içinde yaşamayı seçtiler (Karamustafa, 2017: 62). Toplum içinde yaşamaktan kasit bir meslek sahibi olmaya verilen önemdi. Böylece dervişler ve/veya sûfîlerden ayrılmış oluyorlardı: "Sûfíyim halk içinde, tesbih elimden gitmez / Dilim marifet söyler, gönlüm hiç kabul etmez.", "Hoş dervişim sabrım yok, dilimde inkârım çok / Kulağımdan gireni, hergiz [asla] içim işitmez.", "Dışım derviş içim boş, dilim tatl sözüm hoş / Illla benim ettiğimi, dinini değiştiren etmez” (Tatç1, 2016: 155-156).

Melâmetîler giyim yönünden diş görünüş itibariyle ne dervişe ne de sûfîlere benziyordu. Hatta kendilerini belli edecek hiçbir tarzları yoktu. Yönetim içinde bürokrat olduklarında bile buna dikkat ediyorlardı. Dışarıdan topluma uyarken içeriden uymamaya çalışmaları, melâmetîlerin "güçlü bir konformist enerji ortaya koydu[kları]" şeklinde yorumlanmasına neden olmuştur (Karamustafa, 2017: 63). Ancak "el-melâmet terkü's-selâmet" (Kınanmak, güvenlikte olmay1 terk etmektir.) yaklaşımında olan Hamdûn'un melâmetî oluşu açısından değerlendirildiğinde "konformist" yorumun (2017: 64) yeniden düşünülmesi zorunlu görünüyor.

Meslek sahibi olmaya verdikleri önem, onların en nihayetinde birikime karşı mesafelerini nasıl ayarladıklarını düşündürüyor. Horasan-Nişâbur melâmetîliğinin uzantısı olan Anadolu melâmîliği içinde düşünüldüğünde çözümün Anadolu Selçuklu zamanında genel olarak fütüvvet veya ahi teşkilatlarında kazancın verilmesi veya dağıtılmasıyla (sofra kurmak vs.) bulunduğu söylenebilir (Göçer, 2017: 470-471). Gözünü ve gönlünü (aşkın) Allah'a diken sûfîlerin aksine melâmîlerin dikkati nefsine vermesi, kendiliğin sürekli iç gözetim altında tutulmasını sağlayarak, halkın gözü önünde olmayan bir iç gözetimin Anadolu'da Yunus Emre örneğinde olduğu gibi Allah ile mesafeyi olabildiğince kapatarak Çalab'ın (Allah), nefis gibi insana içkin olan gönüle indirilmesini sağlar: "Gönül Çalab'ın [Allah] tahtı". Allah ile yükseklik (dikey) mesafesi kapatılarak onun her canlı tekinde var oluşu, canlıya/doğaya/eşyaya bakmasına ve konuşmasına zemin hazırlar (Tatçı, 2016: 320, 329 ve 336). Sadece zemin hazırlamakla kalmaz, Allah'ın, insanların gönlünde olduğunu kabul ettiği için gönül kıranın, Allah'ı üzmüş olacağını bilir. Böylece çok uzaklarda, ulaşılması gereken ve ancak ulaşılamayacak kadar uzakta (dikey mesafeli) olan Allah'ı çok yakına, yanı başına getirmiş olur. O'nu sanki semalardaymışçasına arayan sûfîlerin aksine, yeryüzüne indirerek mesafeyi kapatır: "Gönüle Çalab baktı / İki cihan bedbahtı, kim gönül yıkar ise" (Tatç1, 2016: 250). Allah ile dikey mesafe (hiyerarşi) oluşturmayan, O'nu ulaş1labilir yere koyan, Allah'1 diğer insanın gönlü bilen Yunus, yeryüzündeki yönetimleri de kendinden üstte bir yere koymuyordu. Bu sebeple Yunus'ta her şey yerde, yeryüzünde, yüz yüze, bir el uzaklığında, dikey mesafeyi kapatacak şekilde, yataylıkta algılanır. Hiyerarşi bir birikim anlamına geldiği için olası bütün mesafelenmeler yatayda seyreder. Rahmet eğer rahmetse, o da yerden yağmalıdır: "Ben ayımı yerde gördüm, ne isterim gök yüzünde / Benim yüzüm yerde gerek, bana rahmet yerden yağar" (Tatç1, 2016: 139).

Mesleğini de gönlü gibi gören melâmîler eşyaya, çevreye ve zamana kısaca yerküreye/arza karşı mesafesini azaltmış ve fakat dünyaya karşı mesafesini ise açmış olur. Bunda kuşkusuz Bağdat sûfîliğinde deneyim yerine müzakerenin, "Horasan sûfîliğinde" de [melâmetîlikte] müzakere yerine deneyimin olması ilkesi (Karamustafa, 2017: 67) yatıyordu. Bu farka rağmen melâmîlerin kendilerini belli etmeme ilkeleri gereği izlerinin çok erken bir dönem olan 10. yüzyılda silindiğinden bahseden Karamustafa, "sûfîliğin Melâmetiyye'yi yut[tuğunu]" belirtir (2017: 81). Bu nedenle olsa gerek modern Türk tasavvuf tarihi yazınında Anadolu melâmetîliği için melâmîlik ifadesinin kullanılması ve melâmîliğin de tasavvuf akımı veya hareketi yerine meşreb olarak alt bir tonda vurgulanması yaygındır (DİA, 2004: 29/25). Türkiye'de daha çok Horasan erenleri olarak ifade edilenler Arslan 
Baba ve Hoca Ahmed Yesevî çizgisindeki melâmîlerdir, denebilir. Horasan-Nişâbur'da güçlü bir diğer akım da Kerrâmîliktir. İbadet ve zahidliği sergileme, geçim için kazancı yasaklama, dinin duyurulması ve tebliğ edilmesini salık veren Kerrâmîliğin dışa dönük yapısının, Melâmetîliğin sûfîliği kendine daha yakın bularak önce onunla kaynaşmasını ve sonra da muhtemelen sûfîlik içinde yutulmasını (Karamustafa, 2017: 79 ve 81) sağlamış olmalıdır.

Melâmîliğin gizliliği esas alan ilkesinden dolayı söz konusu yutulmanın doğal sayılması da gerekiyor zaten. Çünkü onun bir iddiası yok ama uyması gereken, gösterişe kapılmama ve haz almama gibi bir ilkesi var. İtibar, dava sahibi ve meşhur olma gibi maddî olmasa da manevî bir haz veren şöhretten uzak olması dolayısıyla melâmîlerin; derviş, kerrâmî ve sûfîlerin tasavvufî epikürizmine (manevi hazcıllk) zıt, stoacı bir hayat sürdükleri söylenebilir mi, tartışılabilir. Ancak stoacılık bazı yönleriyle nasıl kendine özgü, başka bazı yönleriyle de nasıl eklektik bir felsefe hareketi (Arslan, 2016: 179) veya ölçülü bir kinizm (2016: 188) ise melâmîlik de kimi yönleriyle eklektik, kimi yönleriyle de kendine özgü yanları olan bir harekettir denebilir. Melâmî için dünya "ne haz ve zevk ortamı" ne de "günah ve kusurlarına bulaşmamak için uzağında durulması ve kaçınılması gereken bir ölümlü dünya"dır (Ülgener, 2015: 105). Tanınmazlığı ilke edindiklerinden tüm "baş"lara karşıdırlar. Çünkü baş, kişiliği tanıtan, vücudun en önemli organıdır. Bu anlamda 'sermâye'ye de (Farsça ser, baş; cap-ital) karşıdır. Başını kaldırmaz, başkaldırma da yapmaz, baş olmayı hesaba almaz, baş olanları ve olmak isteyenleri de kendine yakın tutmazlar.

Stoacıllı̆ın temel düşünce ve kavramlarının Helenistik dönemde evrensel Tanrı anlayışına sahip Hristiyanlığın ortaya çıkmasında, en azından onun zeminini oluşturmada payı vardır. Stoacılara göre erdem en büyük mutluluktur ve bu mutluluk da haz ile tam bir zitlık halindedir. Benimsedikleri ahlak görüşü ruhun korunması, kendine yeterliliği (otarşi), doğaya veya kendi doğasına uygun yaşaması gibi düşüncelerle (Vorlander, 2008: 173) birlikte, ilk kez "görev" düşüncesi üzerinde büyük bir ciddiyetle durmuşlar ve onu uygulamaya koymuşlardır (Vorlander, 2008: 175; Arslan, 2016: 210). Melâmîlikte de kendine yeterlilik (otarşi), başkasına bağımlı olmamak çok önemli görüldügünnden meslek sahibi olmak en ayırıcı özelliklerinden sayılabilir (Göçer, 2017c: 121). Stoacılara göre yine bireysellik ve davranışların ölçüsü olarak insan doğası (Arslan, 2016: 201) ve dünya vatandaşlı̆̆ anlamına gelen bütün insanların eşitliği (2016: 210) ifade edilirken, Yunus gibi Melâmîler de (Gölpınarl1, 1992: 66) "ağyar [ötekiler] dahi yârdır bize... kamu âlem [tüm herkes] birdir bize" diyerek öteki (ağyâr) ve tüm herkesin (kamu âlem) eşit ve aynı oluşunu dile getirerek (Tatçı, 2005: 321) bir yönüyle felsefî bir kavrama, diğer yönüyle de evrenselliğe ulaştığı söylenebilir.

Ancak "[b]ütün antik filozoflar içinde bir tek Stoacılar bu [arzulamama] sanatı[nı] daha da ileri götür"dü (Cioran, 2020: 130). "Hristiyanlığın yükselişiyle, bilge artık örnek olmaktan çıktı, onun yerine... kitlelerin daha kolay erişebildiği azize itibar edilir oldu. Yaygınlaşmasına ve itibar görmesine rağmen Stoacılık imtiyazlı sınıflara has bir etik olarak seçkinlerin tekelinde kal"mıştı (2020: 131). Bu anlamda Yunus tipi melâmîliğin; gerek İyonya'daki antik felsefenin izonomik ilkesinin, gerek Sokrates sonrası Stoacıların bilgesinin ve gerekse Hristiyanlık Anadolu'sundaki azizinin bir karşılığ 1 değilse de bir sentezi gibi durduğu söylenebilir. Yunus'taki miskin vurgusu bu sentezi îma ediyor görünüyor.

$\mathrm{Bu}$ çarpıcı benzerliklerden yola çıkarak söz konusu tasavvufî akım ile felsefî akımların aynılığını ispata çalışmıyorum. Ancak ilkçağ felsefesinde ifade edilenin, yöntemi kelâm veya İslâm felsefesinden farklı olan İslâm tasavvufu gibi başka bir alanda da benzer dile geliş ve tavırlarla karşılaştırılabileceğinin imkânını göstermek istiyorum. Disiplinler, zamanlar ve coğrafyalar farklı olsa da bazen hep aynı şarkı ve duygunun uğultusunun kulaklarda çınlar gibi durduğu hissedilir. Yunus Emre'de de bu ses duyuluyor gibi.

\section{Yunus Emre'nin Kimliği, Yeri ve Zamanı}

Yunus Emre'nin (tahmini 1240-1320) menkıbelerle iç içe geçen tarihi kişiliği ile ilgili en erken bilgiye Uzun Firdevsî (ö.1512) tarafindan yazıldığ düşünülen Vilâyetnâme-i Hacı Bektâsş- 
Velî’de (Tatçı, 2013: 43/ 600) rastlanır. Buna göre Yunus, Sarıköy'de yaşayan bir çiftçidir. Yunus Emre'yi ilim dünyasına 1918 yılı gibi yakın tarihte ilk tanıtan Fuad Köprülü, Sivrihisar ile Bolu arasında Sakarya nehri civarındaki köylerde yaşayan bir Türkmen köylüsü olduğu bilgisini verir (2012: 251). Abdülbaki Gölpınarlı ise ömrünün sonuna doğru Karaman civarında Yerce denilen yerde bir arazi satın alışından Yunus Emre'nin 'yoksul bir adam' olmayıp, hatta "dünyalı̆̆ yerinde" biri olduğunu dahi söyler (1992: 64-65). Buradan da yaşadığı yer(ler) itibariyle Yunus'un, batı ucu Sakarya nehri ile Karaman arasında, doğu ucu ise Hacı Bektaş-1 Velî’nin tekkesinin bulunduğu yer arasında yaşadığı (Tatçı, 2015: 7) sonucuna varılabilir. Konar-göçerlik ile çiftçilik arasında tam olarak hangisini yapıyordu, ya da ikisini de birlikte mi yapıyordu sorusu henüz tam olarak netliğe kavuşmuş gözükmese de bir yanda Moğol istilaları, diğer yanda Haçlı Seferlerinden yorgun düşen Anadolu coğrafyasında özellikle Yunus zamanı öncesi ve sonrasında mesleğin veya geçimin kesin sınırlarından bahsetmek kolay olmasa gerek. Bunun yanında dönemin Anadolu'sunda Hristiyan nüfus içinde Türk ve Müslüman nüfusun görece az oluşunun da, herkesin eşitliğine varacak bir hoşgörü söyleminin şekillenmesinde etkili olduğu söylenebilir.

Türkler için Anadolu'daki kültürün kurucusu kabul edilen isimlere baktığımızda Ahi Evren'i (ö.1261) (Bayram, 2018), Hacı Bektaş-1 Velî’yi (ö.1271), Mevlânâ Celâleddin-i Rûmî’yi (ö.1273) ve Yunus Emre'yi (ö.1320) görürüz. Adı geçenlerin tamamı Horasan'dan Anadolu'ya olan göçü ya yaşamış ya da göç sonrası zamanda doğmuşlardır. Ahi-melâmî olduğu ifade edilen Ahi Evren (Bayram, 2018: 89) hariç tamamının melâmî-kalenderî olduğu bilgisine yer verilir (Ocak, 2011b: 93, $116-117,170,172$ ve 178).

Referans verilen Türkçedeki melâmetle ilgili kaynakların pek çoğu, çalışmanın bu kısmında anılan isimleri melâmî bulmada tereddüt etmez görünür. Söz konusu tarihçilerin melâmîliğin özellikleri arasında; nefsini sürekli kınama ve eleştirmeyi eksik etmemeyi, geçim için bir meslek sahibi olmayı ve cezbeyi-coşkuyu ifade ettikleri bir gerçektir. Oysa coşku ve cezbe melâmîliğin değil, olsa olsa kalenderîliğin bir özelliği olabilir. Melâmîliğin Osmanlı dönemi seyrinde de cezbeye olan yakınlığına veya ilgisine rastlanmamaktadır. Zaten rastlanması da pek mümkün değildir. Çünkü nefsinin hoşuna gidecek şeylerden kendilerini sürekli korumayı esas aldıkları için melâmîlerde cezbe veya coşkunluğa yer olamaz; bu onun bilinmeme veya meşhur olmamaklık olan doğasına aykırıdır. Dolayısıyla melâmîlikle kalenderîliği birbirinden elverdiğince ayrılması gerekir. Bu anlamda Yunus Emre'yi, tıpkı Mevlânâ'da olduğu gibi hem melâmî ve hem de kalenderî saymak (Ocak, 2012: 197 198) makul görünmemektedir.

Diğer taraftan Mevlânâ hariç diğer isimlerin tamamının kendisini veya ailesini geçindirecek bir mesleği (silk-sülûk-meslek) vardır. Ancak Mevlânâ; ekonomik anlamda bir mesleğe sahip olmaması ve cezbeyi merkeze alan yapısı onu melâmîliğe değil kalenderîliğe; iktidara karşı politik bir tehdit oluşturmayan, giyim veya görünüşüyle (hırka vs.) kendini halktan (âvam) ayıran, yüksek bir entelektüel çevrenin (havass) içinde yüksek edebiyat dili olan Farsçayı kullanan, medrese eğitimine sahip (Öngören, 2004: 29/441-448), yönetime madden ve manen yakın (Ocak, 2011a: 83) ve bireysel manevi hazzın/doyumun peşinde görünen yapısıyla da Bağdat sûfîliğine daha yakın duruyor gibidir (Karamustafa, 2017: 65). Öyleyse Mevlânâ'y1 melâmî-kalenderî olarak görmek (Ocak, 2011b: 93-94) yerine sûfî-kalenderî olarak veya sûfîliğin kalenderîlik rengine bürünmüş Anadolu versiyonu olarak görmek daha doğru olacaktır. Yine de onun ne tam bir kalenderî ve ne de tam bir sûfî olduğu söylenemez. Tam bir Kalenderî denemez, çünkü cezbe, coşku ve kendinden geçme gibi özelliklere önem vermesine rağmen (Ocak, 2011b: 94), topluma ve her türlü kurala karş1 politik bir tepkisi de yoktur. Tam bir sûfî de denemez, çünkü kuru bir zühdçü/zâhid de değildir.

Mevlânâ'yı bu nedenle Yunus Emre, Ahi Evren ve Hacı Bektaş Veli çerçevesinde de değerlendiremeyiz. Çağdaşları olan Ahi Evren ve Hacı Bektaş Veli ile arasının hoş olmadığı bilinmektedir (Ocak, 2011b: 95; Bayram, 2006: 77-223). Zaten Ocak (2011a: 79) da söz konusu dört kişi içinden sadece Mevlânâ'yı konformist olarak görür. Ülgener (2015: 131) ise aynı durum için 
"din ve mânâ aristokrasisi” ifadesini kullanır. Muhtemelen bu gibi sebeplerle Türkmenlere mesafeli olduğu da söylenir. "Türkmen" ifadesinin etnik bir kökene işaret etmesinden ziyade iktidarın - ak budun- dışında, yani yönetilenler -kara budun- arasında olmaya işaret ettiği açıktır (Divitçioğlu, 2000: 104, 123, 127-128). Gerek Hac1 Bektaş Veli'nin, gerek Ahi Evren'in ve gerekse Yunus Emre'nin Türkmen zümreden sayılmasını bu çerçevede düşündüğümüzde, geçinmek için mesleklerinden başka tutunacak dalları olmadıkları anlamına gelecektir. Ayrı bir kategori olarak ayrışması mümkün olmasa da ekonomik (mesleki) olarak durulan yerin, politik olarak durulan yeri de belirleyeceği büyük ölçüde söylenebilir. Kolektivist kültür gereği Hacı Bektaş Veli'nin Babaîler isyanında kardeşi Menteş'in ölmesinden dolayı isyanın içinde olduğu sonucunu çıkarttığımızda (Ocak, 2011b: 95), onun kaçarak yıllar sonra başka bir yerden çıkması ise takip edilecek kadar tanınan ve bilinen bir dinî-politik kimliği olduğunu düşündürmektedir.

Babaîler isyanı dendiğinde ifadenin bizzat kendisinin de politik bir tavır olduğu görülür. Olayı isyan olarak görenler, II. Gıyaseddin Keyhüsrev yönetimi yanlısı çevre mi; yoksa dört bininin öldürüldüğü, oniki bininin de hapse atıldığı ifade edilen Alâeddin Keykubat yanlısı ahi veya konargöçer Türkmen çevresi midir? (Bayram, 2004: 44). İhtimal olarak babasının da Baba İlyas, Baba İshak, Hacı Bektaş Veli ve Ahi Evrenlerle birlikte hareket ettiği düşünülürse Yunus Emre'nin tavrı ve sözleri daha iyi anlaşılabilir. Esnafın çarşı örgütlenmesi olan ahilikle, tarım ve hayvancılıkla uğraşan yerleşik yurt arayışlarını sürdüren konar-göçerlerin birbirine olan yakınlığının nedeni, Moğol tehdidi ve onun yarattığı gerilimle anlaşılabilir ancak. Böyle bir ortamda Yunus'un, bu gerilimli gönülleri yatıştırabilmesi ve mülkün her an el değiştirebildiği kaotik havayı dağıtabilmesi için bir yandan kendi içine, bir yandan da Anadolu'nun yaygın havasına yaslanması gerekecektir. Söylemini ăgyârı da (tüm ötekileri) içine alacak şekilde geniş tutacak, kendinden kimseyi ayrık görmeyerek gerilimi dağıtmayı düşünecektir. Çünkü bu gerilim, sadece bir kişinin veya kişilerin kendi başlarına gelen tekil bir olay değil, kendinden önce de bu topraklarda olan bütün ötekilerin pek değişmez, kadim bir sorunudur.

Ötekiliğin Hristiyanlığın içinde ortaya çıkışı da çok erken başlamış görünür. Toplumdan/dünyadan el çekme demek olan manastırcılık (monazo: yalnız yaşama), tek başına yaşamak olabileceği gibi, toplumdan ayrı küçük bir topluluk olarak yaşama da olabilir. Bu yönüyle Mısır'da 3. yüzyılda başlayan manastırcılık, yüzyılın sonuna varmadan Anadolu'ya ulaşabilmiştir. Ancak 1. yüzyıl gibi bir zamanda yine Mısır'da ekonomik durumu kötü olan ve vergilerini ödeyemeyerek köylerini terk eden kişilerin yaygınlığıyla birlikte değerlendirildiğinde (Baskıcı, 2016: 157) bu tavrın daha başka toplumlar ve zamanlarda da ortaya çıkabileceğini düşündürüyor. Tekke sûfîliğine veya dervişliğine kısmen benzeyen manastırcılık 451 yılındaki Kadıköy Konsili kararıyla resmi kilise kontrolü altına alınınca, konformist (uyumcu) olmayan keșişlerin rahatsızlık duyarak manastırları da terk etmelerine neden olmuştu. Ancak bu kontrolü göze alarak Bizans örneğinde olduğu gibi devlet kilisesinin himayesini kabul eden manastırcılığın ana akım (konformist) olarak varlığını sürdürdüğü düşünülebilir.

Leo Huberman, Orta Çağ feodal toplumunu; savaşanlar, dua edenler ve çalışanlar olmak üzere üç sınıfa ayırır (Huberman, 2011: 11). Tam olarak kilise, dua edenler sınıfına giriyor olsa da, manastırcılık için bu, tümden söylenemez. Manastır keşişleri dua etse de, halkın nazarında çoğu zaman keramet sahibi, ermiş olarak görünür, manastır içinde ve topraklarında onlar çalışırd $\iota$. Çalışma yönüyle keşişler, çalışmayan sûfî veya gezgin dervişlere değil, tekkeli melâmîere benzetilebilir. Ancak Huberman'ın çalışanlar diye ayrı bir sınıf olarak ele aldığı kesim gibi bir çalışma değilse de manastırlar, farklı zanaatların öğretildiği, yazma kitapların çoğaltıldığ 1 , düşünsel kültür ürünlerinin ve malikâne araç-gereçlerinin imal edildiği bir üretim, yaşam ve uygarlık merkeziydi (Le Goff, 2017: 127). Sıradan bir Bizans manastırı, tarımsal bir işletme gibiydi. Bağışlardan başka manastır, gündelik tüketiminden fazla gelire ulaşabiliyordu. Başlangıçta yalnız veya toplumdan uzak yaşamayı seçenlerin dini mekânı iken, zamanla bütün aile üyeleri aynı manastırda kalarak bu kuralı ihmal etmeye başladılar (Baskıc1, 2016: 162-163). Böylece onlar da 
sonradan, Ocak'ın 'konformist' olarak nitelediği sûfîlerin durumuna düşmüş oldular. Nedeni kolayca tahmin edilebilir: Vergi yükü ve diğer toplumsal yükümlülüklerden kurtularak kalıcı bir yaşam standardının garantilenmesi. Tercihin kökeninde manastır mülklerinin tıpkı vakıf mülkleri gibi devlet tarafindan el konulamazlık özelliği bulunuyordu (2016: 160).

Aslında pek de şaşılacak bir yanı yok bu durumun. Hayat o kadar tekdüze idi ki, antikitenin koşum takımı Bizans tarihinin sonuna kadar korundu. Bu tarihi ancak savaş değiştirebilirdi. Bu gerçeklik uzun süre Bizans varlığının temel motifi olarak kaldı (Anderson, 2017: 309-310). Dolayısıyla Orta Çağ insanına hükmeden daima güvenlik duygusu oldu (Le Goff, 2017: 358). Küçük köylünün yaşamını sürdürebilmesi için savaş olmaması ve uygun hava şartlarının birlikte sağlanması gerekiyordu (Baskıc1, 2016: 220). Ne var ki Türkler Anadolu'ya gelmiş ve İznik'e kadar fazla zorlanmadan ilerlemişti. Böylece, Bizans yönetiminin Anadolu'da zayıflaması, bir yandan Bizans köylüsü üzerindeki egemenliğinin soylulara geçmesine neden olurken, diğer yandan Anadolu ve Balkanlardaki Bogomil inancina sahip Hristiyan heretiklerinin yeniden canlanmasına sebep oldu. (Anderson, 2017: 324-328). İznik Konsili'nde (325) bastırılan Ariusçuluğun da bu canlanmaya kulak kabartmadıkları söylenemez.

Heretik canlanmayı salt Türklerin Anadolu'ya gelişiyle açıklayamayız. İpek ve Baharat yolu güvenliğinin ve uzak mesafe ticaretinin sağlanmasına paralel olarak, 11-12. yüzyıllarda Avrupa'da profesyonel bir tüccar sınıf doğmuştu (Pirenne, 2001: 162). Selçuklular'ın ticaret yollarına verdikleri önem, bilhassa Anadolu'da daha ileri bir noktaya ulaşmış ve uluslararası ticaretin büyümesine yardımc1 olarak (Özgüdenli, 2009: 36/384-385) yol üzerlerinde veya bazı şehirlerde anıtsal kervansaray ve hanlar yapılmasına, uzun mesafe ticaretinin at, köle, deri, kumaş ve kürklerin en önemli pazarı olan Kayseri civarındaki Yabanlı Pazarı'nın (şimdiki Pazarören) 13. yüzyılda kurulmasina (Tomar, 2007: 34/203-206) neden olmuştu. Ticaret sermayesinin geliştiğini ve büyüdüğünü hem ilk defa bu dönemde basılan paralardan, hem de Avrupa şehirlerinin büyümesinden anlayabiliyoruz. Bu nedenle tüccar (mercator) ile şehirli (burgensis) birbirinin yerine kullanılır hâle gelmişti (Huberman, 37-38).

Büyüyen şehirler Batı'da sivil elitlerin (şehirli-tüccar) elinde birikime, Selçuklu Anadolu'sunda ise siyasal elitlerin elinde birikip harcamaya -lanetli pay- (Bataille, 2011) neden oluyordu. Söz konusu uluslararası ticaretten elde edilen para-birikim (Para: P) Batı'da bir yandan lüks mal-hizmet tüketimine (Mal-hizmet tüketimi: M) giderken bir yandan da ticaretin yeni(den) para-birikimini (Yeni Para: $\mathrm{P}^{\prime}$ ) oluşturuyor $\left(\mathrm{P} \rightarrow \mathrm{P}^{\prime}\right)$; Anadolu'da ise para-birikim $(\mathrm{P})$ yeni parabirikimine değil ama mal-hizmet tüketimi $(\mathrm{M})$ ile mal-hizmet harcamasına (Lanetli pay: L) neden oluyordu. Sonuçta bu dönemde yeni(den) para-birikim oluşmadan para harcanmış $(\mathrm{P} \rightarrow)$ olarak kald1. Yeni birikim ve onu tüketim veya harcama yoluyla kullanma şekli tüm ötekiler açısından bir çeşit şiddet olarak görüldü ve buna tepki gösterildi.

11. yüzyılda Kilise o ana kadar yapmış olduğu birikimi veya yeni parayı $\left(\mathrm{P}^{\prime}\right)$ artık kilise veya katedral inşaatına kullanmaya karar verdi. Ancak birikimin kaynağına yönelik ötekilerin olası töhmetlerinden kaçınabilmek için hemen mucizevi bir şekilde hazine bulduklarını söylemeye başladılar. Avrupa'da ötekilerin söz konusu tepkisine karşı kilisenin ilk yanıtı ise 1022'de Orleans'ta yakılan ateştir. İki asır sonra kilisenin yaktığı bu ateşin adı "baskıcı soruşturma" anlamına gelen engizisyon olacaktır. Kilise, ötekilerin/sapkınların olası tepkilerini susturmak için bir taraftan da aynı yüzyılın başında Fransisken ve Dominiken gibi yeni yoksul-dilenci tarikatlarını devreye soktu. Ancak 13. yüzyılın bitiminde ötekilere karşı zaferi elbette Kilise kazandı (Le Goff, 88-95).

Aynı dönemde Selçuklu Anadolu'suna baktığımızda İran toplumundan devraldıkları toprak ağaları ve bürokrasi ile akrabalık bağları olan kadı ve ulemalardan oluşan din adamı sınıfı yerelde tanınmış ailelerden meydana geliyordu. Bu sınıfın nesilden nesile tevarüs eden birikimi parayla imanın kimde olacağı belli olmayacağı tarzda birikmeye devam ediyor; ticaret birikimi, toprak rantı ve (konformist) sûfîleri de kapsayan din adamları sınıfı ise bir sacayağı oluşturuyordu (Divitçioğlu, 
2000: 123). Divitçioğlu'na göre, din adamı sınıfının büyük koalisyon içinde oluşu, mülkiyetin belgelendirilmesi (legislation, meşruiyet) açısından çok daha önemliydi. Konformist ve/veya zâhid sûfînin mülkiyete karşı sessiz veya paranteze alınabilir duruşu da onun bu koalisyonda durmasına yetiyordu. Başında siyasal elitin (sultan, bey, atabey) bulunduğu bu sacayağına ak budun (buyuranlar); savaşta asker ve iktisat (üretim, zanaat) işlevine sahip yerleşik çiftçi ve göçerevli Türkmen grupları da kara budunu (buyurulanlar) oluşturuyordu (2000: 123-124). İkili temeldeki hiyerarşik ayrım sadece Selçuklularda değil, önceki Türk yönetim yapılanmalarında da bilinen bir özellikti.

Yunus Emre'nin Baba İlyas, Baba İshak ve Hacı Bektaş Veli gibi çiftçi veya göçerevli kara budundan oluşunu, adı geçenlerin kimliği ve eserlerine yönelik belirsizlikten ve hatta yer yer varlıklarının hayali bir varlıkmışçasına ele alınmasından da çıkarabiliriz. Kimliklerindeki flûluk, varlıklarındaki varlıksızlık, birikim ve hiyerarşiden uzaklık, muhtemelen yaşam şartlarının merkeziyetçi olma ilkesine göre işlemeyen kendi(leri)ne yeterlik (otarşi) ilkesine dayanıyordu. "[G]öçebelerin, merkeziyetçiliği devletin temeli olarak gören saltanata hiç mi hiç müdanası ve güveni” olmadığı (2000: 121) için ne Selçuklu Sultanı ne de sarayın neredeyse hiç değişmeyen farisi kökenli vezirleri, onları gulâm olarak bile görmek istemiyorlard1. Unutuşun veya unutturuluşun ekonomi politik bir anlamı olduğu düşünülürse uygarlık adına ne kadar bastırıldıysa anlamın o ölçüde güçlü döndüğü söylenebilir.

Yunus, bu gerilim hattında nerede duruyor ne düşünüyor ve ne yapıyordu? Ya da düşünerek yapageldiği şey nedir? Aşağıda bu soruları sorunlaştırmaya çalışacağız.

\section{Yunus'un Durduğu Yer}

Yunus'un durduğu yer, nazarın manzarayı belirlediği gibi onun söylemlerine içkindir. Söylemi ise tıpkı her yönden ilkelerine bağlı Stoacılar gibi inandı̆̆ ile yaptıkları arasındaki mesafenin kapanıklığı anlamında inanan (mümin) oluşundan kaynaklanır. Düşündüğü ile yaptığ1 arasında bir mesafe yoktur. Yapmadığını söylemek ya da söyleyegeldiğini yapmamak Yunus'a göre yalancılık veya yalanı dava kılmaktır. Dava bu nedenle onda iktidar, sahtelik, birikimcilik ve yalanla ilişkili bir yapının ifadesi gibi görünür: Yunus ko [bırak] yalan davayı, (Tatçı, 2005: 320) Gel imdi miskin Yunus, yolunda yalan olma! (2005: 321). Belki de yokluk özgürlüğ̈̈ne (Cioran, 2018: 14-15) tutunduğu için modern kültür haritası onu sırtında heybesi ile dolaşan etliye-sütlüye karışmaz bir derviş olarak çizer. Ancak gerek Hacı Bektaş Veli'ye gidip buğday isteme efsanesi ve gerekse Karaman'a veya başka bir köye yerleşik bir çiftçi olarak yaşadığına ilişkin bilgiler, haritanın var olan belirsizliğini biraz daha arttırır. Ancak bunlar sorun değildir. Hatta sorun, kimi zaman dillendirildiği gibi onun gerçekten var olup olmaması bile değildir. Gerçekten yoksa bile ona dayandırılan onca şiir ve tek risalesinde Yunus adının geçmesi, üslûbun ve zamandaşlı̆̆ın iç tutarlılığı onu toplumsal bir beklentinin karş1lı̆̆ veya şuuraltı olarak var etmeye zaten yetecektir.

1040 öncesi Selçuklu çevresi artıksız ve iç sömürü yokluğuna dayanan bir ekonomi içindeyken (Divitçioğu, 2000: 105) 13. yüzyıl Anadolu'sundaki Babalılar Olayı (Ocak, 2016) gerilimi, bunun vergilemeye dönüşmüş olabileceğini düşündürüyor. Yunus'un kara budun içinde durduğu yer; barışta iktisatlı, savaşta askerîdir. İktisadı (dirlik) ya zanaatkâr ya da hayvancılık ve/veya ekincilik anlamında bir üretimcilik faaliyeti olarak görebiliriz (Divitçioğu, 2000: 105). Konar-göçerlik yaptığı anda, Karatani'nin dünya tarihinin toplumsal biçimlenişi dediği A dönemi öncesi (2017, 16-100), mülkiyetin topaklanamadığı ve birikimin temerküz edilemediğinden dolayı özgürlük ve eşitlik ilkesinin başat olduğu bir özelliğe sahiptir. İlkeden sapıldığının fark edilmesi veya ilkede anlaşmazlığın çıktığı anda Yunus da, başka bir yere göçecek kadar özgür bir çevrenin içindedir.

Öyleyse Yunus'un Anadolu'da gördüğü nedir? Gördüğü çelişki ve şoklar karşısında yaşadığı travmadan başka ne olabilir ki ona şiir ve risalede söylediği şeyleri yazdırmış olsun? Konar-göçerliği (ve sonradan belki çiftçilik) süresince eşitlik ve özgürlüğe aykırı olacak şekilde ak budunun 
birikimini arttırması, muhtemelen yeni bir olgu değildir. Ancak yeni olan, kendi zamanında kara budundan da (iç) vergi alınmaya başlanması olmalıdır. Bu, çelişkinin ilkidir. İkincisi, Bizans yönetiminin zayıflaması nedeniyle taşradaki köylüsünün elindeki arazilerin bir takım yerel eşraf (kudretliler: dünatoi) ve kilise-manastır tarafından ele geçirilmesi ile köylülügün (fakirler: penetes) eriyor oluşuna (Baskıcı, 234) şahitliğidir. İlki acıtıcı olsa da kendince her ikisi de dışrak bir üzüntü kaynağıdır. Fakat asıl üçüncüsü, Selçuklu'nun Bizans ile karşı karşıya gelmesi veya gelme ihtimalinde asıl zarar gören-görecek olanın zaten iyice yoksullaştırılmış olan köylülüğün olması ve bunun da üyesi olduğu konar-göçerler tarafından gerçekleşiyor veya gerçekleşecek olması Yunus'u bir konuda hassaslaştıracaktır. Hassaslaştırdığ 1 bu konu, hepsinin de temelinde olan birikimin her yerde can yaktığı ve hayati bir mesele oluşudur: Birikim birikmekte, yağma yağmakta, acı acıtmakta ve kara budun da Hristiyan-Müslüman demeden karar(t)maktadır.

İşte Yunus'un dili dillenirken hem kendi adına hem de tüm öteki(ler) adına bu manzarayı, kendince bir eşitliği sağlama adına dağıtmaya (tesviye, düzleme) çalışacaktır. Dağıtılacak olan birikimdir. Birikim; benlik olarak, madde olarak, anlam-mantık olarak, statü-itibar olarak ve Farsçadil/lisan olarak toplam beş alanda gerçekleşmiş ve bunlar dağıtılmaya, yani düzlenmeye girişilmiştir. Aşağıda birikimin sırayla nasıl dağıtıldığı veya düzlendiğini açıklamaya geçebiliriz:

\subsection{Benlik Olarak Birikimin Dağıtılması}

George H. Mead'in Zihin, Toplum ve Benlik'ine yazdığ Giriş'te, bugün bile ahlâkî benliğe erişilemediğinden dem vuran Charles W. Morris, söz konusu benliği bir "sosyal benlik" olarak tanımlar (Mead, 2017: 40). Yunus'un benliği de içinde bulunduğu konar-göçer topluluğun veya aşiretinin ona bakışlarının toplamı veya birikimidir. Jacob Rogozinski' ye göre "bana ben kadar hiçbir şey yabancı ve uzak değildir.” (Rogozinski, 2018: 10). Söz konusu uzaklık, kendiliğine olan uzaklıktır. Bütün ötekilerin, yani "O”ların gözündeki ben-ler kadar olan uzaklık. Benliğe veya benliklere uzaklığı dağıttıkça Yunus, benlikler yok olacak ve kendine gelebilecektir. Kendiliğinin önündeki en büyük engel, benliğidir. Ötekilerin bakış ve yorumlarıyla birikmiş bir benliktir bu (Jung, 2017: 55).

Yalandan uzak oluşu, söylediği ile yaptığı arasındaki mesafenin kapanması (mümin) anlamına gelirken, aynı zamanda ahlâkî bir kişiliğin kurulmakta oluşuna da işarettir. Ancak çevresinin kendisine giydirmiş olduğu 'sosyal benlik'te yaşamını sürdürdüğü müddetçe ontolojik güvensizlik (Laing, 2015: 37) içinde olacaktır. Bilinçlenme anlamına gelen kendini tanıma-bulma sürecinin sarsıcı bir değişim olacağı kaçınılmazdır. Tüm bilinçlenmelerin kaynağı duygu olduğu için durağanlığın harekete geçmesi imkansızdır (Jung, 34). Sarsılma olmaksızın benlikten çıkış olası değildir.

Tekrar belirtmekte bir sakınca yoksa bu çalışmada Yunus'un felsefi bir sistem önerdiği iddia edilmiyor. En fazla, yaşamı bir felsefe gibiydi denebilir. Söylem ve eyleminin birleşimi olan hayatının ekonomi politik bir tarafı olduğunu, bunu da yanlışlanabilmeye imkân verecek şekilde söylemeye çalışıyorum. Bu nedenle bir "sistemi olduğunu göstermeye [ç]alışmak, yapıtın baştan çıkarma gücünü mahvetmektir" (Cioran, 2018: 126). Yunus Emre'nin içinde bulunduğu sözlü kültür döneminde öyle uzun boylu düşünmek zaten mümkün değildir, bunun tek yolu konuşuyor olmaktır. Çünkü "ciddi düşünce, bellek sistemleriyle iç içedir" (Ong, 2014: 49-50). Derdi şiir söylemek olmayan Yunus, şiiri konuşmakta, onu yürütmekte veya onunla yürümektedir. Bu durumda onu kaydetme gibi yazılı kültür anlamında modern bir alışkanlığı da olamaz. Ancak dönüp dolaşıp benzer konularda konuşagelmektedir (söz-eylem birlikteliği: iman). Bunu, özgün olma gibi modern bir meselesinin olmadığı anlamında söylüyorum. Konuştuğu şiir olurken, şiiri de akar gibi konuşmaktadır. Bu anlamda "sözlü kültür akıcılığı, bir çırpıda bol dil dökmeyi özendirir... bugünkü değer ölçülerimize göre gereğinden fazla 'şişirilmiştir'." (Ong, 57). Bu sebeple onun geçerken söylediği veya bir defa vurguladığı ifade veya kalıplardan ziyade, sık sık, arı gibi döne dolaşa söyledikleri ifadelere odaklanmak daha doğru olacaktır. 
Türkçe tasavvuf şiirinde "ben"i en çok kullanan şair Yunus'tur dense yeridir. "Benlik" ise Tatçı'nın hazırladığı Divân'da 18 yerde geçer. Geçtiği yerde de benlikten geçer, benliği dağıtarak geçer, benliği dağıtmak için geçer. Çünkü benlik, çevresinin kendisine yüklediği imgeler birikimidir. Dağıtmazsa, yükün altında kendisi dağılacaktır.

Yunus neden dağıtıyor? Önce bunun anlaşılması zorunludur. Enerjinin hareket edebilmesi için zeminin ya düz ya da iletiyi sağlayanın homojen bir maddeden olması gerekir. Düzlük, eğimsizlik demek değildir. Çukur veya kasis değilse yol, yoldur. Ancak kasis veya çukur varsa o artık yol değildir. Çünkü yol, kesintili olmayan ulaşım hattıdır. Yunus'ta dağıtım, enerjinin bırakıldığında kendiliğinden devir yapabilmesini sağlayabilecek kadar düz veya eğimli olmasına kadar devam eder. Bu işleme dağıtım veya birikimi dağıtım da denebilir. Birikimin (Bir-iki-m) dağıtılması, iki-ye dönüşen bir-in yeniden bir olmasıdır. Bu bir olmaya düzleştirme, tesviye veya düzlük denebileceği gibi pekâlâ tevhid de denebilir. Tevhid denebileceğini kabul edersek Yunus'un bütün bu dağıtımı, tevhidin ekonomi politiği anlamına mı geliyor, yoksa tevhid bizatihi ekonomi politik bir tavır mı oluyor? Makalenin sınırları açısından soruyu, cevaplandırılması gereken bir soru/n olarak ortada bırakmak herhalde daha doğru olacaktır.

Bu bağlamda Yunus'ta enerjinin akışını bozacak kadar boşluk, çukur, tümseklik veya kısaca ayrım yoktur. Örneğin güneş 1şınları bir yere takılmadan gelir; kubbe, güneş 1şığını 1şı̆̆ın bütün geliş açılarından azami faydalanacak şekilde alır. Dünya, evrende hiçbir yere takılmadan dönüşünü tamamlar, bunu bütün gezegenler kendi yörüngesinde yapar. Akışı bozan yerde çatışma çıkar. Çünkü enerji akmamaktadır. Akış parçalanmıştır, bölünmüştür ve ayrılmıştır. Yunus, akışı bozan her şeye karșıdır. Akıșın bozulması, tümseklikten, yani birikimden olabileceği gibi çukurdan da olabilir. Ona göre çukurun varlığı birikimdendir. Bu açıdan yalan, gerçeklik akışını bozmaktadır. Şüphesiz yalana da karşı çıkar: "Dışım biliş̧ içim yâd [yabanc1], dilim hoş gönlüm mürted [yoldan çıkmış] / Yavuz [kötü] işe iyi ad, böyle fitne kanda [nerede] var?" (Tatç1, 2005: 54). Dıştan tanış1k olduğuna içten yabancı olmak, bir enerji kesintisi, çelişki, ayrım, şiddet yaratmaktadır. Enerji akışını kesen ise Yunus'a göre fitnedir. Bu açıdan bütün akışı bozan birikimlerin fitne yarattığını gördüğü için onları, yani birikimleri dağıtmaya çalışacaktır.

Gözüne çarpan ilk birikim kipi benliğidir. Benliğinin merkezinde de adı vardır. Öyleyse kendi adını dağıtmaktan başlamalıdır fitneyi kesmeye: "Ben bu suretten [şekil, yüz] ileri, adım Yûnus değil iken / Ben o idim, o ben idim, bu aşkı sunanda idim" (Tatçı, 2016: 182). Anlaşıldığı kadarıyla Yunus adını, Yunus'a tekkesi veriyor. Yunus, Tapduk Emre tekkesine gelirken veya geldiğinde adını dahi bırakıp gelmiş oluyor. Herkesin bildiği, belki de gelmeden önce de civarda meşhur olmuş olan adını bırakarak/arınarak yeryüzü yürüyüșünü başlatıyor. Bunun teyit ediliși sonraki beyitlerde de görülüyor: "O dost bana ümmî [âvamm, kara budun] demiş, hem adımı Yunus koymuş" (Tatçı, 2005: 168), "Bana bu aşk dolall, adım Yunus olalı" (2005: 176), "Adımı Yunus taktım" $(2005,186)$. Yeni bir ad olarak Yunus adını alması, birikimin ilk yıkımı, ilk dağıtılmasıdır.

Kara budunun kendi içinde görece eşitlik ve özgürlük barındırması ak budunla karşılaşana kadardır. Karşılaşma anlarında ayrım fark edilir. Ancak bu ayrımın fark edilmesi Selçuklu'nun veya Oğuzların Anadolu'ya gelişinden önce olmalıdır. Çünkü söz konusu ikili ayrım ve bu ayrımın yöneten ile yönetilen olarak bölünmesinin yeni bir olgu olmaması, olgunun aşikârllğını doğurur. Așikâr olan ise herkesin gözüne görünmez. Her bakanın göremediği çelişkileri barındırır âşikârlık. Ancak çatışma, karşılaşma anlarında yeniden ortaya çıkar. Yine de bu haliyle bile çatışma yeknesak devam ettiğinde yine görünmezleşir, doğa olarak varlığını sürdürür. Duygu düzeyinde buna kanıksanma, kabullenme denebilir. Ocak'ın Babaîler isyanı olarak ifade ettiği harekette kara budunun bilinçaltı yeniden açığa çıkar. Kaybolan geçmiş veya bastırılmıș ilișkiler dönemi olan toplumsal formasyonun hayata yeniden döneceği beklentisi içine girilir. Tarihin tersinmediği, geriye döndürülemediği, beklenenin beklendiği şekliyle gelmediğinin veya gelemeyeceğinin anlaşıldığı yıllarda Yunus'un 40 yaşını aşmış, birikimin/yönetmenin yerinin daha da sağlamlaşmış olarak 
yerinde durduğunu görmüş olduğunu düşünebiliriz. Yunus burada içinde bulunduğu doğayı görür. Dahası, kendi içinde yeşerttiği ahlâk ile toplumsal etik arasındaki çelişkiyi fark etmiştir. Bu çelişkiyi; boyunun, aşiretinin veya içinde bulunduğu topluluğun önde gelenlerinin fark etmemesi olası değildir. Bunu Yunus da fark etmişse onun farkı nerededir?

Öyle anlaşılıyor ki Yunus, bu çelişkiyi sadece aşiretinin ya da konar-göçerlerin bir sorunu olarak görseydi, belki yine söylediği sözler ak budun-kara budun mücadelesinden öteye geçmemiş olacaktı. Mevlânâ ve Mevlevî tarikatı hakkındaki bilgileri Farsça olarak derleyen mevlevî Ahmed Eflâkî'nin (ö.1360) Menâkıbü'l-Ârifîn (Yazıc1, 2004: 29/114-115) adlı eserinde "Yunanlılar" adına rastlansa bile (Eflâkî, 2006: 205, 698 ve 752) 'Yunus' adına yine rastlanmayacaktı. Adına rastlanmaması, Mevlânâ ile Yunus arasında bir irtibatın olmadığına ikna ediyor (Bayram, 2018: 139). Ancak Yunus'un gördüğü çelişkilerin, kendisinden 40 yıl sonra vefat eden Ahmed Eflâkî tarafından 'görülmemesine' de neden oluyor. Bu sebeple Yunus'un gördüğü çelişkiler, çelişkinin derinliğinin ve yaygınlığının daha fazla olmasını gerektiriyor. Meselenin sadece bir ak budun-kara budun meselesi olmadığını fark etmiş olmalı.

Daha doğru anlayabilmek için döneminde var olan boşlukları bir varsayım olarak doldurmayı denemek gerekir: Yunus, Moğollar sonrası Anadolu'da kendi çevresine ahilerin bir kısmının Moğol yanlısı yönetime yakın durmuş olduklarını; kara budunun içindeki bazılarının bir çelişki olarak birikimli hale geldiğini; dirliği bozulanın sadece konar-göçerler değil, içine yerleşiyor oldukları ve her geçen gün Bizans köylülerinin geçimini biraz daha kaybettiklerini; Bizans köylülerinin geçiminin daralmasının nedeni olarak Yunus'un içinde bulunduğu toplulukların bazı uygulamalarının olabileceğini; Yunus'un da kaygısını çektiği sorunları ve çelişkileri görüp yollara daha önceden düşen Anadolulu Hristiyan mistikleri veya keşişlerini görmüş olabilir. Dahası, Ermeni, Rum veya Türk topluluklar içinde ticaret (bezirgân) sermayesinin (birikim) giderek büyümesinin bir sonucu olarak borç yükümlülüğünün yaygınlaşması ve vergi borcunu ödeyemeyenlerin yeriniyurdunu terk edip başıboş bir şekilde ova dağ arası uzanan insan kalabalıkları ile de karşılaşmış olabilir... Bütün bunların hepsi ya da bazısıyla da karşılaşmış olabilir. Fakat çelişkinin her halükârda sadece kendi hayatında ve yakın çevresinde olmadığını anlamış olma ihtimali çok yüksektir.

$\mathrm{Bu}$ çelişkilerin tamamının Yunus zamanında çıkmış olduğunu iddia etmiyorum. Çelişki, toplumsal biçimlenmelerin birbiri ile karşılaşması sonrasında olabileceği gibi toplulukların kendi yapılarının değişmesinden kaynaklanıyor da olabilir. Çelişki dediğimizde, herhangi bir toplumsal biçimlenmeye ya da Karatani'nin deyişiyle yürürlükteki baskın mübadele tarzına (2017), aynı zaman ve mekân içinde ancak baskın olmayan mübadele tarzlarını yürüten çevrenin etik değerleri doğrultusundaki bakışını kabul etmiş oluruz. Bu açıdan çelişkiyi görmek bir mesele, görmemek ise bambaşka bir mesele ya da yaygın ifadeyle dertsizlik veya meselesizliktir. Yunus bu anlamda çelişkiyi görebilmiş, bu da onu bir dert sahibi yapmıştır: "Kişi dertli olunca, dermân isteyen olur / Kendi derdinin dermânını sormayan, âşık mıdır?", "Ĕger vuslata erdin ise bu dert ile ayrılık nedir?" (Tatç1, 2016: 122), "Dert âşıklar dermânıdır, dertli aşıklar ganîdir / Kadîr ve kudret ünüdür işiten [ler] dir sesimi" (Tatç1, 2005a: 333), "Ben dert ile âh ederdim derdim bana dermân imiş" (Tatçı, 2005a: 126). Öyle ki dertsiz insanı insan bile olmayan kayaya benzetmeye kadar gider iş: "Dertsizlere benim sözüm, benzer kaya yankısına" (2005a: 346).

Şüphesiz dert ise insan-Allah ilişkisi yönüyle dikey, insan-dünya ilişkisi (doğa, insan, zaman ve eşya) yönüyle de yatay bir boyuta sahip olup tek boyutlu değildir. Şiirlerinde bolca geçen 'dünya'ya atıflarının fizik yerküre anlamındaki arz ile bir alakası yoktur. Ancak arzı kastettiği yerler az da olsa vardır (Göçer, 2017b ve 2017c). Yunus dünyayı; doğa, insan, zaman ve eşyayı mülkiyetine geçirerek biriktirme veya biriktirme hevesi olarak görür. Yoksa mesleği önemseyen bir melâmînin fizik dünya ile ilişkisini koparması düşünülemez. Geçim açısından değil, dünyaya birikimcillik açısından karşı çıkmış olur. Bu açıdan Yunus'un 'dünyaya saldırması' geçime, geçimciliğe, üretime 
ve meslek sahibi olmaya bir saldırı değildir. Dilindeki ve eylemindeki dünya yergisi; doğa, insan, zaman ve eşya olarak dünyanın birikimciliğine yöneliktir.

Birikime karşı çıkışı önce $a d \imath$ üzerinde biriken ünü sıfırlayıp Yunus adını alarak, sonra da benliğini dağıtmaya çalışarak yapacaktır: "Miskîn olagör bâri benlikten ırak yürü / Gönlünde benlik olan dervîşlikten traktır [uzak]." (Tatçı, 2005a: 94). "Senlik-benlik terk edip yokluk evine girip / Aşktan içip esriyip [sarhoş olup] varlı̆̆ terk eder misin" (Tatçı, 2005a: 248). Benliğini kaldırabildiğinde ancak kendiliğine ulaşmış olacak ve kendini bilecektir. Kendini bulduğu yerde de Rabbini bulmuş olacaktır. Kendine gelmeden benliği geliştirmeyi, içini imar etmeden dışarısını bayındır kılmaya benzetir: "İçin imar olmadan, dışındaki imaret nedir" (Tatçı, 2005a: 69).

Yaşar Nuri Öztürk nefs ve ruhu, benliğin iki parçası olarak görür. Tanrısal özelliklerin ruhta toplandığını; kötülük ve şehvet gibi niteliklerin de nefse ait olduğuna işaret eder (Öztürk, 2014: 130131). Yunus şiirlerinde ruh bir defa, nefs ise benlik ile aynı çoklukta ve büyük ölçüde aynı anlama gelecek şekilde geçer. Nefs-benlik ve dünya sarkacın iki ucu gibi işlev görür Yunus’ta. Sarkaç dışa salındığında dünyaya doğru, içteyken de nefs-benliğe doğru hareket etmiş gibidir. Bu durumda nefsbenlik insan duygularındaki kötücül, şehevî-kösnül hırs dolu duyguların birikmişliği veya birikim arzusu uyandırması iken, dünya ise doğada belli bir nesneyi (doğa, insan, zaman ve eşya) biriktirme veya biriktirmeye yönelik eylemlerdir. Daha başka bir anlatım ile nefs-benlik insanın iç doğasındaki duyguların birikimi iken, dünya ise insanın dış doğasındaki nesnesi belirli olan şeylerin birikimi veya biriktirme arzusudur: "Aşk kadehinden içip nefs dileğinden geçip / Hak yoluna er gibi durmayan âşı mıdır" (Tatç1, 2005a: 49), "Nefs ili oldu harâb, kibir ayaklarda toprak/ Gitti perde ve utanç dost gözüme tuş oldu" (2005a: 377), "Nefstir eri yolda koyan, yolda kalır nefse uyan" (2005a: 385), "İbadetler başıdır terk-i dünya /Eğer mümin isen ona inanasın" (2005a, s.271), "Geç benlik davasindan, söyle sözün hasindan / Ol Allah korkusundan, benzi onun sarl gerek” (2005a, s.144), "Ko nefsin dileğini, can beslerisen ..... Tekebbürdür nefs, sultanı bilmez / Onun için sipâhî, dirlik dirilmez" (2005b, s.31).

\subsection{Maddi Olarak Birikimin Dağıtılması}

Yunus'un hem varlık sahasına ilk çıkışı hem de çıkarken maddiyatı reddine ilişkin meşhur menkıbedir: Yoksul bir köylü olan Yunus, o yılki kıtlık nedeniyle meşhur Hacı Bektaş Veli’ye gidip buğday istemeye karar verir. Hacı Bektaş'ın, "buğday mı, nefes mi?" sorusuna önce, buğday, der ve alıp köyüne doğru tekrar yola koyulur. Ancak fazla ilerlemeden kendi muhasebesini yaparak, buğdayı iade edip nefes istemek için geri döner. Buğdayı verip vermediği bilinmiyor ama nefes için Tapduk Emre'ye yönlendirilir (Gölpınarlı, 2016: 47-48). Yunus, bașta adı olmak üzere dıșta dünyayı, içte de benliğini-nefsini dağıtırken maddi birikimi dağıtmaması düşünülemez. Karatani'nin dünya tarihinin yapısını mübadele tarzı üzerinden okurken David Graeber de borç üzerinden ikna edici bir okumaya girişis. Borç (2015) adlı eserinde Graeber dini, hukuku, ahlâkı, ekonomiyi, kısaca toplumu yapılandıran düzenin borç olduğunu iddia eder. Faizle verilen borçların geri ödenememesi halinde borçlu olanların ödeyinceye kadar aileleri dâhil köle oluşunu farklı milletler, medeniyetler ve dinler üzerinden anlatır. İslam da, ahlâkî ilkelerin mevcut borç kölelik ilişkisini zamana yayarak kalkmasının zeminini oluşturmayı seçtiği için birden yasaklayıp kaldırma yoluna gitmez. (Aydın ve Hamîdullah, 2002: 26/246-248) Çin'de ise Budizmin Tükenmez Hazineler adlı manastır uygulaması kölelik-borcunu kaldırma yerine onu yeniden yapılandırır (Graeber, 2015: 278, 288-289). Bu manastırların etrafında ticari çiftliklerden başka binlerce borç kölesi (rehine) işçilerin çalıştıkları yağ atölyeleri, hanlar, değirmenler ve dükkânlar da bulunuyordu. Kapitalizm'in zorunlu ve sürekli büyüme ilkesi burada da vardı (Graeber, 278-279).

Graeber'e göre yerleşik çiftçilerde görülen bu tip rehine işçilik (kölelik) uygulamalarını örgütleyen Çin ve Hint’te bizzat manastırlardı. Çin hükümetleri farklı zamanlarda bunları engellemeye çalıştıysa da başarılı olamamış, MS. 845 yılında yapılan operasyonlarda 4600 manastır, un değirmenleri ve dükkânlar tarumar edilmiş, 260.000 rahip-rahibe evlerine gönderilmek üzere 
görevlerinden uzaklaştırılmış, 150.000 tapınak içşisi de (serf) rehinelik esaretinden kurtarılmıştır (Graeber, 279). Klasik Hint Budizmi'nden Çin Budizmi'ne geçen "karmik borç" kavramı, borçlu ölenin hayvan veya köle olarak doğuşunu açıklamakta ve böylece köleleştirilmiş insanları bunun bir yazg1 olduğuna ikna etme amacını gütmekteydi (Graeber, 276). Diğer taraftan konar-göçer Türkmenler arasında kölelik uygulamasına dair bir bilgiye rastlanmamakta. Bunun nedeni yerleşik bir çiftçi düzeninin olmaması olabilir. Ancak Memlük, Babür ve Abbasi yönetimlerinde köleler kullanıldı. Bunların tamamının savaş esiri olduğu söylenemez. Kimisinin mesleği asker, kimisinin de Türk steplerinden satın alınan veya köle olarak satılan kişiler olduğu biliniyor (Graeber, 288).

Ayrıca Kalenderîlerin gezgin veya sapkın dervişler olarak dolaşması da sadece İslam'a özgü bir durum değildir. İslam öncesi dinlerde de benzeri dervişlik hallerinin varlı̆̆ biliniyor. Aynı Kalenderîler gibi Budist ve Mani rahipleri de gezerek dileniyorlardı. Ayrıca Kalenderîler para, altın ve gümüş hariç verilen her şeyi almak zorundalardı (Ocak, 2011a: 10). Budist ve Mani rahipleri gibi Kalenderilerin de kökeninin dile getirildiği gibi Hint bölgesi olduğunu düşünmek makul görünmektedir. En eski medeniyetlerden olan Çin ve Hint bölgesindeki köleliğin yaygınlığ veya kölelik düzeyindeki yaşamın kast sistemi gibi düzenlemelerle korunmuş olması, Budist ve Mani rahipler için olmasa bile borç veya kölelik korkusundan kaçan köylülerin, yaşamını Kalenderîler gibi yaşamayı ilke edinmeleri sonucunu doğurmuş olabilir. Bununla, Kalenderîlerin tarihsel ve yaşambiçimsel kökeninin Çin ve Hint bölgelerinden borç ve kölelik korkusu nedeniyle kaçan köylülerin olabileceğini kastediyorum: Tek veya toplu, bekâr ve her türlü toplumsal kurala karşı hassasiyetleri olan bu tipin, zaman ve mekâna bağlı olarak sonradan başka bir şekil ve inanca bürünmüş olması son derece olasıdır. Çünkü topluma karışıldığı an borçluluk düzenine girilmiş oluyordu. Birikimi mümkün kıldığı için yerleşiklik, çiftçilik veya şehir gibi yapılar, borçluluk düzeninin kurulmasına varıyor. Dinler de borcun söz konusu kölelik doğurucu şiddetini azaltmak veya kaldırmak üzere, var olan ahlâkî (borç) sözleşmenin insanlık için daha güzelini gerçekleştirmek üzere gelmiş görünüyor: "Ben güzel ahlâkı tamamlamak için gönderildim" (Buhari, 2018: 207).

Yunus'un şiddet ve şiddet hikâyeleri ile dolu bir dönemde yaşadığı olayları düşündüğümüzde bunun muhasebesini yapmadığı düşünülemez. Hesâbîliğe varmayan bir hasbîlik muhasebesi içinde birikim-mülk arzusu ile şiddetin birbirine paralel yürüdüğünü defalarca görmüş olmalı ki eserlerine yansıyan da bundan başkası değildir: "O mal ki Halîl'indir hayırlara yilterler [iletir] onu / O mal ki Kârûn'undur ıssı [sahibi] hiç rahat bulmaya" (Tatçı, 2005a: 307), Yunus, varlık evinden başka mülk tanımaz: "bu mülk varlık evidür" (Tatçı, 2005a: 47). "Yunus akıllı isen bunda, mülke sûret bezemegil [mülk sahibi olma yolunu süslü gösterme!] / Mülke suret bezeyeneler kara toprak olmuş yatar" (2005a: 87).

Hem melâmî olup hem de mülke karşıtllık nasıl bir arada olabiliyor diye sorulabilir ve hatta sorulmalıdır da. Buna verilebilecek cevap ancak şu olabilir: Geçinmek için herkes kadar mülke evet, ama birikime varmaya başladığı zaman hayır! Yunus da böyle düşünmüş görünüyor. Zira onun geçinmek için gezgin dervişler (Kalenderîler vd.) gibi dilenmediğini, konformist sûfîler gibi kendini elbisesi ile göstermediğini ve bir tekkeye de sahip olmadığını görüyoruz. Ya konar göçerevli, ya çiftçi, ya da esnaftır. Kesin bir bilgi olmadığı için en azından son dönemleri için göçerevli bir çiftçi olduğunu düşünmek daha makul görünüyor. Ama ayrımlar noktasında kesinlik olamayacağı için gezgin derviş ve sûfîlerle kesişen az da olsa birtakım benzerlikler olabilir. Bu durum, onun net olup olmaması değil, sözlü kültür dönemi insanının müphemliğe açık ve müphemlikten beslenen özelliği dolayisiyladır (Bauer, 2019; Ong, 2014).

Toplumsal yapı içindeki ayrımı, direncin ve duvar örmenin bir türevi olarak düşündügümüzde güvensizliği besleyeceği açıktır. Çünkü "ayrımın olduğu yerde güvensizlik vardır" (Krishnamurti, 2018: 38). "Ayrı bana ben demeyem, kimseye sen demeyem / Ya kul ya sultan demeyem kalsın işitenler tana [şaşırmaya]" (Tatçı, 2005a: 24). Enerjinin akışını bozacak ve her türden ayrıma yol açacağı için korkuyu ve parçalanmayı yeniden üretecektir. Bu da güvensizliği 
pekiştireceği için René Girard'ın bir nesneyi sahiplenme arzusunun öteki insanlarda da sahiplenme mimesini tetiklediğini, bu ortamda oluşan mimetik rekabet sonucu mimetik kriz (Girard, 2018) denilen şiddet sarmalına düşülmesine neden olacaktır. "Şiddet, bir arada tutmaz" (Han, 2017: 57), ayırır, korku salar. Korkunun olduğu yerde ise özgürlük olmaz.

Özgürlük, diyor Jiddu Krishnamurti, hiçbir korku olmadığında zihin ve kalbin hareketidir (2018: 38). Korku, ayrımdan kaynaklı bir duygu olduğuna göre Yunus'un mülke ve edinime karş1 düzleştirici, dağıtıcı ve yıkıcı tavrının altında Allah dışında her şeyden uzak olma veya özgür olma arzusu (da) yatıyor olamaz mı? Birikim(li) ve birikimsizlik(li) şeklinde oluşan her türden ayrıma karş söylemini kurmakta ve adeta savașmakta olduğu söylenebilir. Karatani'nin var olduğunu iddia ettiği İyonya' daki izonomide de özgürlük olmadan ekonomik eşitliğin, ekonomik eşitlik olmadan da özgürlüğün hiçbir anlamı yoktur (2018: 47).

Özgürlük ancak ayrımlar olmadığında veya her türden eşitlik olduğunda kullanılabilen bir şeydir. Ama özgürlük biriktirilemez, tıpkı sevgi gibi. Birikimsizler ile birikimliler arasında toplumsal (yatay) ve hiyerarşik (dikey) bir mesafe olmadığında özgürlük, zeminini yaratmış olur. Otoritenin varlığı bu anlamda yönetene işaret ettiği için zorunlu olarak bir de yönetilenin olması ayrımına dayanır. Bu ayrımın bizatihi kendisi veya varlı̆̆ zaten otoriteyi de doğurmuş olur. Yunus her anlamdaki ayrıma olduğu kadar buradaki ayrıma da karşıdır. Bu ayrımları bazen dava kılmak şeklinde de ele alarak eleştirir: "Her davadan geçen kişi, Hak'tan yana uçan kişì" (Tatçı, 2005a: 22), "Şerîat oğlanları bahis dava kilırlar / Hakikat erenleri davaya kalmadılar" (2005a: 51). Ayrıma karş1 gösterdiği bu hassasiyet, bir yönüyle de eşyanın şeyleşmesine (Bewes, 2008) ya da metalaşmasına gösterdiği tepkidir. Pazar alışverişini veya pazarlığı parça başı ya da hesaba gelecek şekilde yapma yerine herhangi bir ayrıma tabi tutmadan yapmayı tercih eder görünür: "Elif okuduk ötürü / Pazar eyledik götürü / Yaradılmışı severiz / Yaradandan ötürü” (Gölpınarl1, 1992: 56).

Ahmet Güner Sayar, Sabri Ülgener'in 'Osmanlı'nın kapitalizme geçememesinin en büyük engelinin batınî tasavvuf olduğunu söyler"ken (2001: 127), kendisi de "tasavvuf terbiyesi"nin "bizde... iktisadi madde ile yoğrulmayı gözden düşür" düğünü söyleyerek Ülgener'in görüşünü teyit eder (2001: 120) ve buna “Türk töresi"ni ilave etmeyi ihmal etmez (2001: 117-119). Örneğin pazart götürü eyleyen Yunus'un bu tavrı tasavvufî midir yoksa Türk töresiyle mi ilgilidir? Her ikisi ile de ilgili gibi görünse de daha çok şehir dışılıkla ilgili gibi görünüyor. "Şehir dışıllk" ifadesini kullanmamın sebebi, konar göçer veya köylülüğü bir süreliğine aynı parantaze almak istememle ilgili. "Bir süreliğine" ifadesi de onların aynı toplumsal biçimlenmenin bir görünümü olmadığını ancak şehir dışıllk bağlamında aynı yerde geçici bir süre durmasını belirtmek için kullanılmıştır.

Bilindiği üzere Yahudilik, Hristiyanlık ve İslam şehir(li) dinidir. Şehir olması dolayısıyla da inançlarının şehir dışı yapılanmalara (köy, göçebelik) ulaşması dirençle karşılaştığı için zaman almış, yayılmaları daha çok şehirler arası veya şehirlerde olmuştur. Bu sebeple şehir dinleri şehir dışını, pagan-köylü (Latince paganus: köylü) görüyor ve onların inançlarına da hurafe yani "akla ve gerçeğe aykırı düşen aldatıcı söz" (Yel, 1998: 18/381-382) diyerek dikkate alınmamalarını salık veriyorlardı. Öyle ki Ermeniler, Hristiyanlığı 301 yılında ilk kabul eden devlet olmasına rağmen 19. yüzyıl sonu kırsal bölgelerinde ve İngiltere'nin 17. yüzyıl sonu kırsal bölgelerinde Hristiyanlık öncesi pagan inançlarının hâlâ çok güçlü olduğu olduğu tespit edilmiştir (Matosian ve Hoogasian, 2006: 183). Bu açıdan şehirdeki din ile şehir dışındaki din pratiklerine ve algılamaya bakarken her zaman dinden $\mathrm{mi}$, din öncesi yerel inançlardan $\mathrm{m}$ kaynaklanıyor diye fazlasıyla ihtiyatlı olmak gerekiyor.

Dinî yaklaşımın politik tarafına baktığımızda neler görürüz? Din ortaya çıkarken dünyaimparatorlukları bile olsa şehir-devletlerinin içinde (şehir, medine, polis) örgütlendiklerini ifade etmiştik. Şehir-devletlerinin bir yöneticisi (sultan, melik, kral) vardı ve Tanrıları da bir tane idi. Bu sebeple dinler şehirlerde ortaya çıktığındaki temel tartışma Tanrı'nın varlığı değil, Tanrı'nın birliği idi. Çünkü Tanrı'nın olmadığını söyleyen hiç kimse yoktu. Mesele, şehirdeki yönetici kralın tekliği 
gibi Tanrı'nın birliği idi (Hacımüftüoğlu, 2011: 90). Şehir (polis) kralı veya sultanı ile ilgili söylenen ve yapılan her şey politik olurken, şehir dışında (köy veya konar-göçerlik, göçerevlik) yaşayanların şehir kralı veya sultanına yönelik her ifade ve davranışı politik kabul edilebilir mi? Örneğin şehir dışındaki Yunus veya onun çevresinin tavır ve söylemleri politik kabul edilebilir mi? Şehir dışının yaban ve pagan ve hatta hurafelerle dolu görülmesi sadece Hristiyanlığa özgü bir mesele midir? Mehmet Eröz'ün Orta Asya, Selçuklular ve Osmanlllardaki yörüklerin (konar-göçer) iktisadî zihniyeti arasında saydığ “ "ufak hesaplara bakmama temayülü” şeklindeki ifadesi (Eröz, 1991: 119) ne ölçüde sadece din ve tasavvufla ilişkili görülebilir? "Pazarı götürü eylemek"le "ufak hesaplara bakmama temayülü" aynı çevrenin zihniyet dünyasını yansıtmaz mı? Sayar'ın "Türk töresi" mi devrede, şeklindeki soruları çoğaltılabilir. Ancak şehirde yaşamamasına ("Ben bu yurtlu değilim, bunda durup n’ideyim / Nice nice tutsakl, tuzak üzdüm giderem”) rağmen (Tatç1, 2005: 222), Yunus'un politik bir tavrı doğal olarak olmasa da ekonomi politik bir tavrının var olduğu herhalde söylenir. Çünkü politik olmak için şehirde (polis) yaşamak gerekir (Arendt, 2016: 62). Şehirdeki sûfînin "Allah'ı", "şehir" dinlerinin "Kral Tanrı"sını çağrıştırır: "Görünmez kral Tanrı" ve "Sorgulanmayan kral Tanrı" (Hacımüftüoğlu, 138-143 ve 146-147). Oysa şehirli olsun şehir dış1 olsun melâmînin "Allah'ı", kendi nefsi kadar yakın ve sorgulanır, ötekinin gönlü kadar da görünür ve yakın durumdadır.

\subsection{Anlam-Mantığın Dağıtılması}

Yunus'un en tartışmalı şiiri hiç şüphesiz Çıkdım erik dalına diye başlayan meşhur şiiridir. Şiir Osmanlı zamanından beri tartışılıp yorumlanıyor. Yorumlayan üç meşhur yorumcu Muslihiddin Mehmed Efendi (Şeyhzade, ö.1544), ikinci Yunus olarak da bilinen Niyâzî-i Misrî (ö.1694) ve İsmail Hakkı Bursevî'dir (ö.1725). Yorumlar daha sonra artmıştır (Tatçı, 2010: 120). Ancak söz konusu üç yorumcunun yorumlarına baktığımızda, aralarında önemli farklar olmasına rağmen üçünün de ilahi sırlara işaret eden, irfanî bilgilerle dolu mecaz ve sembollerin çözümlemeleri olduğunu anliyoruz (Ak, 2015: 7-8). Her ne kadar Yunus'un şiirleri vahdet-i vücûd düşüncesi çerçevesinde bir semboller sistemi ile okunmaktaysa da bu şiir, ayrıksı bir yapısı olduğundan dolayı daha çok yorumlanmıştır. Her şeyin bir yapılış sırası ve mantığının olduğu, o mantık gözetilmeden yapılanların boşa gideceği ve bazı beyitlerin ayet ve hadislere göndermede bulunduğu gibi geniş bir yorumlanabilme yelpazesine sahiptir şiir (Tatçı, 2016: 308-309):

\section{Çıkdım erik dalına onda yedim üzümü \\ Bostân ıssı [sahibi] kakıyıp der ne yersin kozumu}

Kerpiç koydum kazana poyraz ile kaynattım

Nedir diye sorana bandım verdim özünü

Iplik verdim çulhaya sartp yumak etmemiş

Becid becid ismarlar gelsin alsin bezini

Bir serçenin kanadın kırk kağnıya yüklettim

Çifti dahi çekmedi kaldı şöyle yazılı

Bir sinek bir kartalı kaldirtp vurdu yere

Yalan değil gerçektir ben de gördüm tozunu

$\cdots$

Bütün Yunus şiirlerinden apayrı duran bu şiiri, diğer yorumcular gibi yorumlama niyetinde değilim. Ancak yapısal olarak bakıldığında Yunus'un, dizge yapısını bozmaksızın yine bir birikim olan anlam ve mantığı dağıttığı söylenebilir. Yapılan bu dağıtma ile yukarıda yapılan yorumlara halel getirilmiş, onlara karşı çıkılmış, yanlış bulunmuş olunmuyor. Şiir anlam ve mantığı dağıtmasına rağmen yorumlanmayı hâlâ mümkün kılabiliyor. Tasavvuf, biraz da yaratılan bu müphemlik sayesinde zenginliğini, çekiciliğini ve sağlığını koruyabilmiş gözüküyor. Onun her şeyi dağıtıp yağma edebilecek bu yapısını başka şiirleri de destekleyecektir zaten (Tatçı, 2016: 234-235): 
Cânlar cânını buldum bu cânım yağma olsun

Assı [kazanç] ziyandan geçtim dükkânım yağma olsun

Ben benliğimden geçtim gözüm hicâbın açdım

Dost vaslına ulaştım gümânım [şüphe] yağma olsun

Benden benliğin gitti hep mülkümü dost tuttu

Lâ-mekân kavmi oldum mekânım yăgma olsun

...

Yunus ne hoş demişsin bal u şeker yemişsin

Ballar balını buldum kovanım yağma olsun

\subsection{Statü ve İtibarın Dağıtılması}

Her türden birikime karşı olan, birikimin tesviyesine, düzleştirilmesine çağrı yapan Yunus, herhalde sadece söylemekle kalmıyordu. Bilindiği üzere o, söylem ve eylem birlikteliği (mümin) içindeydi. Toplumsal mesafeye (yatay) karşı olduğu kadar yönetimsel (hiyerarşik, dikey) mesafeye de karşıydı. Yönetim dendiğinde de hiç kuşkusuz kendi toplumu için beyleri ve muhtemelen diğer toplumlar için de onların yönetim çevresini kastediyordu (Tatçı, 2005a: 73):

"Gitti beyler mürveti [mertliği, cömertliği]

Binmişler birer atı

Yediğ i yoksul eti

İçtiği kan olısar [olunca]".

İtibar olarak soyluluğa da karşıdır. Soyluluk burada, ak budunun birikimsellik içinde olması anlamına geldiği gibi bir soyun yönetimselliğinin biriktirilmesi olarak da tanımlanabilir. Toplumsal bir suç olarak görülen soylu (itibarlı) olmamayı ise erenlerin yardımı/himmeti olarak görür: "Soya sayılmamak suçu erenlerin himmetidir" (Tatçı, 2005a: 48). İtibarlı olmaktansa ar-namusu terk etmeyi bile yeğler: "Âr-namusu bıraktım / Külümü suya attım" (2005a: 84). Her ne kadar beyler/hanlar, Dede Korkut hikâyelerine yansıyacak kadar yoksulların doyurulması meselesinin bilincinde (Zeyrek, 2015: 195) olsa da, tarih bu bilincin askıya alınışlarıyla doludur. Yunus'a göre itibar ile azgınlık arasında bir bağ vardır, bunun sebebi de nefs gölüne dalmaktır: "Beyler azdl yolundan, bilmez yoksul halinden / Çıktı rahmet gölünden, nefs gölüne dalmışlar" (2005a: 88). Kendini bu anlamda beylerle yarıştırmak yerine kara budunun arasında görür: "Ol dost bana ümmî [âvâm, kara budun] demiş, hem adımı Yunus komuş" (2005a: 68). Kendine ümmî (âvamm) denmesi, kara budunun üyesi olduğunun da işaretidir. Bunu vurgulaması toplumsal ve topluma karşı mesafesinin olmadığının itirafı olarak da okunabilir: "Padişah olan kişiye, sekbân [köpek bakıcıs1] olmak olmaya / Çün[kü] n'ideyim ben dahi, mihnet [s1kınt1] tadını tadaram." (2005a: 323).

"İman” tanımı, özgünlük derdinde olmamasına rağmen olabildiğince sade ve özgündür: "Neyi seversen imanin odur / Nice sevmeyesin [sevmediklerin de], sultanın odur" (Tatç1, 2005b: 32). Üslûbunun bu sadeliği, arılığı ve sözünün dolambaçsızlığı dünyayı görecek kadar mesafede oluşundan ileri gelir. Bu mesafe, içinde bulunduğu çevre ile olan mesafesizliği kadardır: Görecek ve duyacak kadar yakın. Yunus'un sadeliği, "Neyi seviyorsan, onun müminisin!" şeklinde ifade ederse ancak anlayabilecek bir çevrede yaşamasından kaynaklanır. "İman"1 sevmekle (sevdiği şeyle), "sultanı" da sevmemekle (sevmediği şeyle) eşleştirmesi çok çarpıcıdır. Aynı zamanda seslendiği çevrenin "sultan"a, yani hiyerarşiye (statü-itibar) bakışını da ele verir. Bu karşı oluş poliste (şehir, Konya) olmadığı için politik bir tavır da değildir. Çünkü meselesi ya da derdi, "daha iyi bir yöneten veya yönetim" arayışı değildir. Onun bu karşı oluşu, yöneten ve yönetilen ayrımının bizatihi kendisinin yarattığı mesafede oluşan kibire yöneliktir. Kibir ise ayrımdan doğar: "Sakın olma kibir ile yoldaş / Kibir nerdeyse onunla savaş" (2005b: 44). Birikimin politik görünümü olan hiyerarşiye karş1 kibir (yüksekte olma histerisi) ile savaşında tercihi ya da 'savaşma yöntemi', şiddet içeren bir savaş değil, alçakta olmayı beğenmekten ibarettir: "Yunus alçaklı̆gl [mütevazıllğı] yavlak [çok] 
beğendin / Onun için bu aşk yerine kondun" (2005b: 57). Kötücül bir duygu birikimi olan öfke de şiddet içerdiği için ona da aynı şekilde karşıdır. Bu sebeple öfke (şiddet) ile imanı yan yana düşünemez: "Buşu [öfke] kimdeyse imanı gider" (2005b: 60).

\subsection{Dilsel Mesafenin Dağıtılması}

Birikimden kaynaklı her türlü mesafeyi kaldıran, düzleyen ve dağıtan Yunus, gerek Selçuklu sarayındaki ve gerekse tekke ve tarikat çevrelerinde kullanılan dildeki (Farsça) mesafeyi de dağıtmış gibidir. Farsçayı hem resmî dil olarak kullanan ve hem de tekkenin şiir dili olarak kullanan ak buduna karşı Türkçe nefes söyleyerek bir dağıtım işlemi gerçekleştirir. Bu dağıtma, ak budunun Farsçasına karşı kara budunun Türkçesi ile karşı çıkarak sağlanır. Bu, şiirlerinde Farsça veya Arapça kelime kullanmadığı anlamına gelmez. Bu ayrımlar bugünkü anladığımız anlamda net ve keskin değildir. Ama sonuçta bir yönelim olarak ortaya Yunus Türkçesi çıkmıştır, ya da Türkçe, Yunus'la çıkmıştır ortaya. Yunus'un Türkçeyi kullanışı, Farsça ile açılan ak budun-kara budun arasındaki mesafenin dil bağlamında yeniden kapanışı demektir. Oluşan yabancılaşmanın kaldırılarak ortanın büyütülmesi, sınırların, ayrımların ve aykırılıkların kaldırılması hedeflenir. Bilir ki bu ayrımlar ve mesafeler olmasaydı Babalılar Olayı veya 'isyanı' olmayacak, binlerce insan ölmeyecek, çocuklar öksüz ve gelinler dul kalmayacaktır.

$\mathrm{Bu}$ anlamda Yunus'un Türkçede diretmesi, basit bir dil zevki meselesi değil, hayat-memat meselesidir. 'İsyan'a, hareket ve toplumsal çığlıklara mesafenin açılması olarak bakıldığında, 'heretik' olarak görülmeyecek ve Yunus gibiler böylece kötü bir şöhrete maruz kalmayacaklardır. Ancak kalırlar: "Aş̧ çengine düşenin melâmet olur işi / Onun için bednâmdır [kötü şöhretlidir] miskin Yunus'un adı" (Tatçı, 2005: 289). Söyleyerek eylediği şiir, kara budunun duygularında bir kıpırdanmaya veya duygulanıma neden olmayacaksa ona göre bu nice okumakdır? Kara budunla kurulamayan yatay ilişkinin en başında bu dil sorunu gelmektedir: "Yunus Emre der hoca, gerekse var bin hacca / Hepsinden iyice bir gönüle girmektir." (Tatç1, 2016: 144). Yunus eğer böyle söylemeseydi, sadece o dönemin değil, bu dönemin bile gönlüne nasıl girebilirdi ki!

Türkçe söylemek, emeği ile geçinen esnaf (ahi), ekinci (çiftçi) ve göçerevli Türkmenlerle konuşmak demektir. Konuş-mak için aynı yaylaya, aynı köye veya aynı çarşıya kon-mak gerekir. Konmadan kon-şu /komşu olunmaz. Konşu-komşu olamadığınızla da konuşamazsınız. Yunus'un konuşabilmesi için Türkçe konuşan komşularını duyabilmesi gerekiyordu. Fakat Türkçe konuştu diye Yunus, ağyârı ve kamu âlemi (tüm ötekileri) bir ayrıma mı tabi tutmuş oldu? Hayır. Yunus, emeği ile geçinen, başkasının emeği ile de geçinmeyen tüm herkesle / kamu âlemle (Hristiyan, Müslüman, Yahudi, yaban vs.) emeği ile geçindiği müddetçe kendine eş / bir görür. Hatta kendini, bu eşitliğin sağlanması adına alt bile görür. Ama emeği ile geçinmeyi din kadar, iman kadar merkeze alır. Öyle ki, peygamberin bile emeği ile geçindiğini, peygamberliği emeği sayesinde aldığını söyleyecek kadar emeği her şeyin ölçütü/kriteri olarak vurgular: "Süleyman zenbil ördü, kendi emeğini yerdi / Onun ile buldular, bunlar peygamberliği”" (Tatçı, 2016: 283). Bu sözler her türlü anlama gelebilecek şekilde manalı ve eğlence olsun, kafiye tutsun diye okunmaya kalk1lırsa Yunus'un onlar için de bir çift hediyesi vardır: "Yunus'un bu sözünden sen mâni anlarsan / Konya minaresini göresin bir çuvaldız" (Tatçı, 2005a: 111).

Peki emek, meslek, esnaf (ahi) ve melamet vurgusu Yunus'un miskinliği ile çelişmiyor mu? Çünkü Yunus her firsatta miskinliğini söylüyor, neredeyse bütün şiirlerinin son beyti miskin Yunus ile bitiyor. Tek kelimeyle eğer Yunus anlatılmak zorunda kalsaydı hiç kuşkusuz o, miskin olurdu. Eğer miskini, tembel tembel oturmak, hiçbir iş yapmamak şeklinde anlarsak, buna çelişki dememek için hiçbir neden yok. Öyleyse Yunus'un miskinlikten anladığı başka bir şey olmalı. Hem emek hem melamet ve hem de miskinliğin bir arada olabilmesi için birbiriyle çelişmeyen yanları olmalı. Aksi 
takdirde Yunus'u, bulunduğu ortama veya çevreye göre konuşan, her çevrede farklı bir Yunus kişiliğinin sergileneceği anlamına gelen bağlamsal ahlâka sahip bir kişi olarak düşünmemiz gerekecek. Bu da onun kamu alemi (tüm ötekileri) bir-aynı gören görüşüyle çelişmiş olacak. Öyleyse Yunus'u tüm bu çelişkilerden uzak tutabilmek için onun miskinden ne anladığını bilmemiz hayati önemdedir.

\section{Yunus'u Anlamada Temel Kavram: Miskinlik}

Aşık-aşk, dost, gönül, derviş ve miskin gibi temel kavramların Yunus'u anlamada önemli bir konuma sahip oldukları anlaşılıyor. Ancak bunların içinde de özellikle miskin anlaşıldığında söz konusu diğer kavramlar buna göre bir varlık-anlam kazanıyor. Yunus'un yukarıda ifade edilen birikimin dağıtılmasının da miskinlikle doğrudan alakalı olduğu anlaşılıyor. Ayrım doğurduğu için şiddete neden olan birikimi dağıtacak duygu durumu, içinde şiddet barındırmadığı için ancak miskinlikle mümkün hale gelmiş gözüküyor. Çünkü miskinlik, bir arzulamama durumu ya da arzunun ortadan kaldırılmasıdır. Dikkat edilirse arzulamama, bilgeliği de ifade eder. Bu durumda Yunus'ta miskin, bilgeliğe karş111k geliyor. Öyleyse miskin nedir ve kimdir?

Varlı̆̆a sevinmemek ile yokluğa üzülmemek (Tatç1, 2016: 367) arasında durabilmeyi kendine mesele/dert edinen Yunus'un duruşu, miskinliğinin anlaşılabilmesi için bir ipucu veriyor gibidir. Öyle sakin ve sükûnet içindeki hiçbir dünyevi değişiklik onu rrgalamıyor. Sakin ve sükûnet içinde olabilmeyi sağlaması, onun zaten miskinliği ile aynı anlama geliyor. Arapça bir kelime olan miskin, "oturmak" anlamındaki "SeKeNe" fiilinden geliyor. Dilimizde bir mahallede oturana "sâkin" veya "meskûn", sessiz durana "sâkin" veya "miskin", sessizliğe "sükûnet", birini yatıştırmaya "teskin etme", sakinleştirici ilaca Osmanlı Türkiye'sinde ve yakın zamana kadar "müsekkin" deniyordu. Bütün anlamların ortak yanına baktığımızda ayrım yaratmayan, birliği bozmayan, bozulmuş birliği tekrar eski birlik seviyesine çıkaran, gel-git veya in-çıkları olmayan, düzlemde düz devam eden bir duygu durumu gibi görünüyor.

Gel-git veya in-çıkları olmayan derken, şiddet, çarpıklık, acı, üzüntü ve eziyet daha doğrusu ayrım gibi bir bölünmüşlük yaratmayan yeknesak hale işaret ediyor. Bunun nedeni de hırstan yoksun olmak, yani biriktirme ve biriktirme arzusundan yoksunluk... Miskin Yunus demek, biriktirmekten uzak, biriktirenlerden uzak, biriktirmeye neden olan muhteris duygulardan da uzak demek. Bütün birikim ve birikime neden olan duygu, çevre, dil, mantık, statü-itibar yapılarından, kısaca dünyevî ilişkilerden uzak olmak demek. Uzak olmakla kalsa iyi, onları dağıtmaya da vardırıyor işi. Yani çiftçi (ekinci), göçerevli veya esnaf olmaktan başka çaresi yok miskinin. Mesleklidir miskin. Ama biriktirmeye varmayan bir mesleki hayattır söz konusu olan. Aksi taktirde kendi gibi bir miskinin ekinciye benzetilmesini ne diye ifade etsin: "Miskin Âdem oğlanını benzetmişler ekinciye / Kimi biter kimi yiter yere tohum saçmış gibi” (Tatç1, 2005a: 374).

"Sakin insandan kork!" sözü sanırım konuyu anlamamıza yardımcı olabilir. Ondan korkulması, onun sarsılmazlığı ile ilgili biraz da. İlkelerine o kadar bağlı ki, ne kimseye karışır ne de kimsenin kendisini ilkesine uymaktan alıkoyana müsaade eder. Büyük heyecanlar ve ani duygu parlamaları yoktur onda. Mistikler için "uysal insanlar sanılırlar" der Cioran (2018: 130). Bu, onların bildikleri, düşündükleri, söyledikleri ve yaptıkları ile aralarındaki mesafenin kapalı (mümin) oluşuyla ilgilidir. Hiç kimsenin bir şey vermesiyle tavrında bir değişiklik yaratamadığı gibi ondan bir şey alınmasıyla da onu kimse eksik bırakmış olamaz. O tüm hallere razıdır. Onu pasifizmden ve bugünkü anladığımız anlamda tembel miskinden (Ülgener, 2015: 144) ayıran şey, propaganda yapmadan ve bir dava gütmeden hâl ve sözleriyle insanlar(1)a konuşması ve görüşmesidir. Bu anlamda "miskinlik bizi lafı fazla uzatmaktan... kurtarır." (Cioran, 2020: 118). Hatta tüm fazlalıklardan... 
Elbette kanaate bakışı da miskinlik çerçevesinde olunca kanaatkâr olmayanı haramî olarak görür Yunus. Genel düşünce ve tavrı ile birlikte düşünüldüğünde Yunus'un kanaatkâr olmayanı birikimcil olarak gördügü aşikârdır. Öyleyse kanaatkâr, tüm fazlalıklara direnen kişidir. Gündelik çalışma veya meslek, üretim veya tüketim, geçimliğin ötesine geçtiğinde kanaati (had, sınır) aşmış olacağından harama girmiş olacağını düşünür: "Kanaat geldi oturdu tahtı aldı / Harâmîler hemen yollarda kalde" (Tatç1, 2005b: 41).

\section{Sonuç}

Konformist sûfîlik ile gezgin dervişlik (kalenderîlik, haydârîlik, vs.) arasında Horasan (Nişâbur) - Anadolu melâmîlik hattının bir uç melâmîsi olan Yunus Emre, Anadolu Selçuklu döneminin sonu ile Osmanlı'nın ilk dönemlerinde yaşamış bir kişilik olarak kendini miskinliğe adamış görünür. Miskinlik bugün her ne kadar tembellik ve pasifizm çerçevesinde ele alınsa da o bu kavramı yeni baştan tanımlayarak yaşamış gibidir. Bir taraftan meslek, emek ve çalışmaya önem verirken diğer taraftan itibar ve statüye değer vermeyerek nefsini sürekli kontrol altında tutup kibre düşmemeyi ilke edinmiştir.

Yunus'un herkesten biri (âvamm, ümmi, kara budun) olarak, herkesin içinde ve herkesle beraber çalışması ve geçimini kimsenin sırtına yüklememesi melâmîliğinin bir sonucu olup meşhur olma, ün yapma ve başkasının emeğiyle geçinme ona en uzak olan özelliklerdendir. Ne makamı ne tanınırlığı ve ne de tekkesi vardır. Her türlü ödül ve haz verici şeylere karşı mesafelidir. Ulaşmak istediği Allah çok uzaklarda değil; bir el uzatımı yakınındaki dostlarının gönlünde olduğu kadar tüm ötekilerin de (ağyâr ve kamu âlem) gönlündedir. Herkesi kendine bir ve eş görür. Bu da onun doğal olarak eşdeğerliğe ('eşitlik') değer verenler içinde değerlendirilmesine neden olur. Allah dışında hiçbir otoriteyi dikkate almayan tavrı onun hem dini algılayışı ve hem de toplumsal formasyonu çerçevesinde şekillenen yöneten ve yönetilen ayrımına yönelik karşıtlı̆̆ını besler. Yöneten ve yönetilen ayrımı her türden birikimin yarattığı bir çarpıklıktır. Benlik, madde, anlam-mantık, statüitibar ve dil olarak toplam beş alanda oluşan toplumdaki bu birikim görüngüleri kişilerde olduğu gibi toplum içinde de korkuyu doğurur. Korku doğuran birikim dağıtıldığında (tesviye, düzleme, birikim sahibi olanların olmayanlara vermesi) korku da ortadan kalkmış, bir anlamda 'özgürlük' sağlanmış olur. Tesviye veya düzleme anlamında kullanılan birikimin dağıtılması ile kastedilen, birikimin mutlak anlamda "sıfirlanması" değil, birikimliler ile birikimsizlerin aynı seviyeye getirilmesidir. Örneğin, 100 birim sahibi A ve 2 birim sahibi B'den oluşan iki özneden sadece A'nın birikimi tesviyeye (sıfirlanmaya, düzlenmeye) tabi olmayacak, aynı zamanda B de bu düzlemeye tabi olacak. Düzleme $(100+2=102: 2=51)$ sonucunda A ile $B, 51$ gibi aynı düzlemde/seviyede buluşmuş olacaklar. $A$ ve B'nin birikimlerinin her farklılaşmasında yapılacak işlem $A+B / n$ olacak, yani düzleme ve tesviyeye tabi tutularak birikim dağıtılmış olacaktır. Özgürlük ve eşitliğin aynı anda sağlanması (izonomi) nasıl İyonya'da Yunan anakarasından sağlanan göçle gerçekleşmişse Yunus'un uygulamış göründüğü bu ilkeler de Türklerin Orta Asya'dan Anadolu'ya süreğen göçü dolayısıyla gerçekleşmiş görünüyor. Belirtilmesi gereken bir husus da şudur: Özgürlük ve eşitlik, Yunus’ta kavramsal düzeyde yok ve fakat yaşamsal düzeyde vardır. Özgürlük yerine serbest kavramını kullanmak daha doğru olacaktır. Çünkü Yunus'un başı Allah'a bağlıdır (Farsça ser, baş;) best ise bağli). O'nun dişında hiç kimseye bağ-lı değildir. Bu anlamda İyonya'daki izonomik olgudan etkilenmeden ziyade, yerleşik hayata bir göç sonrası yeni geçmiş veya yerleşik hayatta oluşan borç bağından kurtulmayı düşünen kişi ve topluluklarda beliren ekonomi politik durum olarak ortaya çıkıyor.

Ancak söz konusu beş alanda oluşan birikimin dağıtılma yöntemi şiddet içermez. Çünkü şiddet de bir kötücül (muhteris) duygu birikimidir. Bu yüzden yöntem de şiddet içermemelidir. Yunus'un birikimi dağıtma yöntemi miskinliktir. Miskinlik ise geçimini sürdürecek çalışmanın birikime neden olmaya başladığı an kesilmesi ilkesidir. Buna kanaatkârlık da denebilir. Miskinlik veya kanaatkârlık, fazlasına talip/sahip olmama veya arzulamama hâlidir. Geçimlik düzeyde 
çalışmanın birikim doğurması halinde birikim olan fazlanın (artık) başkasına aşkla ve gönülden verilmesi (dağıtımı) gerekir.

Bu anlamda miskinlik, antik felsefedeki bilge ile Hristiyan Anadolu'daki azizin izonomik çerçevede sentezlenerek 13-14. yüzyılda yeniden varlık-anlam kazanmıştır. Yunus; akbudunkarabudun ayrımını reddetmekle kalmaz, şiddet içerdiği ve borç yüklediği için bütün ayrımları (akbudun-karabudun) kaldırarak bu ikisini ortada buluşturmaya çalışır. Bu da ekonomi politiğin yeniden tasarlanması anlamına gelecektir.

Eğer Yunus "halk İslam"1 içinde değerlendirilmeye devam edilseydi, birbirine neredeyse zit görünüme sahip sûfîlik ile gezgin dervişlik imgesi arasındaki ayrım fark edilir olmayacaktı. Ancak söz konusu ayrımın yapılması bir "görme" imkânı sunsa da üçüncü bir ayrıma veya senteze (orta) gitmeden Yunus'un resminin daha net ortaya çıkmasına yetmeyecekti. Orta yol diyebileceğimiz bu üçüncü uğrağa veya senteze Anadolu melâmîliği veya Horasan-Nişâbur melâmetîliği eksenindeki Anadolu melâmîliği denebilir. Eğer sadece tekkeli sûfì sayılsaydı Yunus, onun emeğe vurgusu ve meslekli oluşu boşa çıkardı; ya da sadece gezgin dervişliği kabul edilmiş olsaydı ne meslekli oluşu ve ne de toplum içinde yaşaması kabul edilebilirdi. Dolayısıyla onun melâmetli oluşu veya melâmîliğin sûfîlik içinde "eridiği" iddiası kabul edilemez. "Erimek" yerine belki kendilerini gizlemeyi bildiler denebilir. Ama öyle bile dense "eriyerek yok oldular" anlamı çıkartılamaz. Sadece Yunus gibilere işaret edilemez. Bu yüzden onlara "işaret edilemeyenler" de denebilir. Edilselerdi zaten "unutulmuş" ya da "unutturulmuş" olmazdı. Ama aynı zamanda onun unutuluşu veya unutturuluşu, "tasavvufun orta yolu" olduğunun da bir işareti olarak okunabilir. Uç olsaydı, bütün uçlarda olduğu gibi gözün unutamayacağ bir imge olarak "göz önünde" kalır ve zaten biliniyor olurdu. Aşırılıkları ve gürültüleri açısından $u c ̧$-lar bütün zamanlarda dikkati çektikleri için varlığını sürdürmede daha başarıll 'gösterilmiştir'.

Diğer taraftan Yunus'un ne Stoac1 bir bilgeye ve ne de Hristiyan azizlerine benzetilemeyeceğini söylerken amacımız, ondan ne bir filozof yaratmak ve ne de aziz öykünmeciliği yapmaktı. Eğer sadece benzerliklerini vurgulamış olsaydık, bu iddianın belki üzerinde düşünülebilirdi. Sadece resminin daha da netleşmesi için benzerliklerini vurgularken benzemezliklerini de göstererek her iki tipolojinin bir orta yolunu bulduğunu fark etmiş olduk. Tek bir alan değil de farklı alanlar üzerinden okunduğunda Yunus'un ne dediği ve ne yaptığı daha belirginlik kazandı. Sanıldığının aksine "miskin"liğin (kanaatkârlık) pasifistlikten ziyade tüm fazlalıkları (arzu, artık, birikim vs.) dağıtıcı ve meslekli (silk) bir "ortacılık” olduğu sonucuna varılmış varıldı.

Kojin Karatani'nin İyonya için ortaya koyduğu yönetme ve yönetilmenin olmamas1, özgürlük ve eşitliğin aynı anda gerçekleştirilmesi, kölelik düzenine dayanan demokrasiden daha değerli ve öncel olan izonomi ile mümkündü. İyonya'da yaşanan bu ekonomi politik düzen Yunan anakarasından (Atina) Ege'ye göç ile gerçekleşmişti. Göç sonrası İyonya, büyük aile ve kabilelerin toplumsal gücünün geride kaldığı, bireyler arası yani birebir ilişki ve yabancı, kadın, ihtiyar demeden herkesin eşitliğine dayanıyordu. Artık değerin (birikim) ve köleliğin oluşmaması, sahipsiz boş toprakların varlığına dayanıyordu.

Yunus Emre de göç süreci içinde olan bir dönemin karakteridir. Ancak göç, kabile ve boylar ile birlikte gerçekleştiği için bireyler arası ilişki gerçekleşmez. Yunus dönemi ilişkileri toplumsal veya kara-budunsal bir ağırlık etrafında şekillenir. Bu anlamda İyonya'da olduğu şekliyle izonomik ilke, toplumsal düzen yerine sadece Yunus gibi bazı kişilerin bireysel düzeninde/bilincinde kendini göstermiş gibidir. Böylece Yunus, hem eşitliği sağlamaya yönelik bir tavır almış, hem de birikim yüklerinden kişinin bağını çözdükçe onu özgürleştiren ve yeğnileştiren bir tavrı sergilemiştir. Sıkça kullandığı çalab, âşık, dost ve miskin gibi kavramları, kişiye yük gibi gelen bağlarından çözerek aşkın gerçekliğe ancak bu yeğnilikte ulaşılabileceğini bizatihi yaşamıyla göstermiştir. 


\section{Kaynakça}

Ak, S. (2015). Çıktım Erik Dalına. Büyüyen Ay Yayınları.

Anderson, P. (2017). Antikiteden Feodalizme Geçişler. İletişim Yayınları.

Arendt, H. (2012). Devrim Üzerine. İletişim Yayınları.

Arendt, H. (2016). İnsanlık Durumu. İletişim Yayınları.

Arslan, A. (2016). İlkçă̆ Felsefe Tarihi - Helenistik Dönem Felsefesi 4. İstanbul Bilgi Üniversitesi Yayınları.

Arslan, A. (2018). İlkçă̆ Felsefe Tarihi - Sokrates Öncesi Yunan Felsefesi 1. İstanbul Bilgi Üniversitesi Yayınları.

Baskıc1, M. M. (2016). Bizans Döneminde Anadolu - Iktisadi ve Sosyal Yapr (900-1261). Phoenix Yayınevi.

Bataille, G. (2011). Lanetli Pay. Dost Kitabevi.

Bayram, M. (2004). Destursuz Bağdan Üzüm Yiyenler. Kömen Yayınları.

Bayram, M. (2006). Ahi Evren-Mavlânâ Mücadelesi. Yayınevi belirtilmemiş.

Bayram, M. (2018). Ahi Evren Hâce Nasirü'd-din Mahmud ve Ahi Teşkilatının Kuruluşu. Çizgi Yayınlar1.

Bewes, T. (2008). Şeyleşme. Metis Yayınları.

Cevizci, A. (2014). İlkçă̆ Felsefesi. Say Yayınları.

Cioran, E. M. (2018). Var Olma Ĕ̈ilimi. Metis Yayınları.

Cioran, E. M. (2020). Parçalanma. Metis Yayınları.

Çakmaktaş, B. (2017). “Sarı Abdullah Efendi’nin Hayatı, Eserleri ve Tasavvufî Görüşleri”. Yayımlanmamış Doktora Tezi, Sakarya Üniversitesi.

Devellioğlu, F. (1996). Osmanlıca-Türkçe Ansiklopedik Lûgat. Aydın Kitabevi Yayınları.

Divitçioğlu, S. (2000). Oğuz'dan Selçuklu'ya (Boy, Konat ve Devlet). Yapı Kredi Yayınları.

Eflâkî, A. (2006). Ariflerin Menkıbeleri. Kabalcı Yayınevi.

El-Acluni, İ.b.M. (2019). Keşfü'l Hafa. Beka Yayınları.

Eröz, M. (1991). Yörükler. Türk Dünyası Araştırmaları Vakfi.

Foucault, M. (2016). Doğruyu Söylemek. Ayrıntı Yayınları.

Girard, R. (2018). Dünyanın Yaratılışından Beri Gizli Kalmış Sırlar. Alfa Yayınları.

Göçer, K. (2017a). “Ahiliği Potlaç Kültürü Üzerinden Yeniden Düşünmek”. Selçuk Üniversitesi Edebiyat Fakültesi Dergisi, 37: 470-471. (erişim 09.01.2019).

Göçer, K. (2017b). “Kuran'daki Arz ve Dünya Kavramlarının Osmanlı İktisat Zihniyeti Üzerine Etkisi". 15. Uluslararası Türk Dünyası Sosyal Bilimler Kongresinde Sunulan Bildiri, Komrat/Gagavuzya Özerk Bölgesi, Moldova, Eylül 11-12: 70-82.

Göçer, K. (2017c). "Melâmîliğin Türklerin İktisat Zihniyeti Üzerindeki Uzun Dönem Etkisi”. Türk Dünyası Araştırmaları. 117(227): 115-132.

Gökberk, M. (1996). Felsefe Tarihi. Remzi Kitabevi. 
Gölpınarl1, A. (1992). Yunus Emre ve Tasavvuf. İnkılâp Kitabevi.

Gölpınarlı, A. (2016). Menâkıb-ı Hünkâr Hacı Bektaş’ı Veli Vilâyet-Nâme. İnkılâp Kitabevi.

Graeber, D. (2015). Borç: Il 5000 Yll. Everest Yayınları.

Hacımüftüoğlu, H. (2011). Allah'ın Krallı̆̆ı. İletişim Yayınları.

Han, B-C. (2017). Şiddetin Topolojisi. Metis Yayınları.

Huberman, L. (2011). Feodal Toplumdan Yirminci Yüzyıla. İletişim Yayınları.

İmam Buhari. (2018). El-Edebü'l-Müfred. Beka Yayınları.

Jung, C. G. (2017). Dört Arketip. Metis Yayınları.

Karamustafa, A. T. (2017). Tasavvufun Oluşumu. İstanbul Bilgi Üniversitesi Yayınları.

Karamustafa, A. T. (2019). Tanrının Kural Tanımaz Kulları-İslâm Dünyasında Derviş Toplulukları (1200-1550). Yap1 Kredi Yayınları.

Karatani, K. (2017). Dünya Tarihinin Yapısı. Metis Yayınları.

Karatani, K. (2018). İzonomi ve Felsefenin Kökenleri. Metis Yayınları.

Köprülü, M. F. (2012). Türk Edebiyatında İlk Mutasavvıflar. Akçağ Yayınları.

Krishnamurti, J. (2018). Niçin Eğitiliyoruz?. Ganj Yayıncılık.

Laing, R. D. (2015). Bölünmüş Benlik. Pinhan Yayıncılık.

Le Goff, J. (2017). Ortaçă̆ Batı Uygarlı̆̆ı. Doğu Batı Yayınları.

Matosian, M. K. ve Villa, S.H. (2006). 1914 Öncesi Ermeni Köy Hayatı. Aras Yayıncılık.

Mead, G.H. (2017). Zihin, Toplum ve Benlik. Heretik Yayınları.

Ocak, A.Y. (1992). Osmanlı İmparatorluğunda Marjinal Sûfilik: Kalenderîler (XIV-XVII. Yüzyıllar). Türk Tarih Kurumu Basımevi.

Ocak, A.Y. (2011a). Osmanlı Sufïliğine Bakışlar. Timaş Yayınları.

Ocak, A.Y. (2011b). Türk Sufiliğgine Bakışlar. İletişim Yayınları.

Ocak, A.Y. (2012). "Yunus Emre: 13-14. Yüzyıllar Arasında 'Bir Garip Derviș-i Kalender-reviş' Yahut Önce Kendi Zaman ve Zemininin İnsanı.” Yunus Emre. (Der. Ahmet Yaşar Ocak). Kültür ve Turizm Bakanlığı. 183-198.

Ocak, A.Y. (2016). Babaîler İsyanı. Dergâh Yayınları.

Ong, W.J. (2014). Sözlü ve Yazılı Kültür. Metis Yayınları.

Öztürk, Y.N. (2014). Tasavvuf ve Tarikatler I. Yeni Boyut Yayınları.

Pirenne, H. (2011). Ortaçağ Avrupa'sının Ekonomik ve Sosyal Tarihi. İletişim Yayınları.

Rogozinski, J. (2018). Ben ve Ten. Pinhan Yayıncılık.

Sayar, A.G. (2001). Osmanlı'dan 21. Yüzyıla. Ötüken Neşriyat.

Sayın, Z. (2018). Ölüm Terbiyesi. Metis Yayıları.

Sencer D. (2000). Oğuz'dan Selçuklu'ya (Boy, Konat ve Devlet). Yapı Kredi Yayınları.

Taş, İ. (2011). Türk Düşüncesinde Kozmogoni-Kozmoloji. Kömen Yayınları.

Tatçı, M. (2005a). Yûnus Emre Divânı. Millî Eğitim Bakanlığı Yayınları. 
Tatçı, M. (2005b). Risâletü’n-Nushiyye. Millı̂ Eğitim Bakanlığı Yayınları.

Tatçı, M. (2010). "Yunus Emre Şerhleri”. Uluslararası Yunus Emre Sempozyumu Bildirileri, İstanbul: İstanbul Büyükşehir Belediyesi Kültürel ve Sosyal İşler Daire Başkanlığı Kültür Müdürlüğü Yayınları.

Tatçı, M. (2015). Yunus Emre ile Aşk Yolculuğu. H Yayınları.

Tatçı, M. (2016). Yunus Emre Divan. Diyanet İşleri Başkanlığı Yayınları.

TDV İslâm Ansiklopedisi (1994). Tahsin Yazıcı, İstanbul: TDV İslâm Araştırmaları Merkezi, "Ebû Hafs el-Haddâd" maddesi, 10: 127-128.

TDV İslâm Ansiklopedisi (1997). Mustafa Kara, İstanbul: TDV İslâm Araştırmaları Merkezi, "Hamdûn el-Kassâr" maddesi, 15: 455-456.

TDV İslâm Ansiklopedisi (1998). Ali Murat Yel, İstanbul: TDV İslâm Araştırmaları Merkezi, "Hurafe" maddesi, 18: 381-382.

TDV İslâm Ansiklopedisi (1998). Tahsin Yazıcı, İstanbul: TDV İslâm Araştırmaları Merkezi, "Haydar, Kutbüddin" maddesi, 17: 24-25.

TDV İslâm Ansiklopedisi (2000). Süleyman Ateş, İstanbul: TDV İslâm Araştırmaları Merkezi, "İhlâs" maddesi, 21: 535-537.

TDV İslâm Ansiklopedisi (2001). Nihat Azamat, İstanbul: TDV İslâm Araştırmaları Merkezi, "Kalenderiyye" maddesi, 24: 253-256.

TDV İslâm Ansiklopedisi (2002). Mehmet Âkif Aydın, Muhammed Hamîdullah, İstanbul: TDV İslâm Araştırmaları Merkezi, "Köle" maddesi, 26: 237-246.

TDV İslâm Ansiklopedisi (2004), DİA, İstanbul: TDV İslâm Araştırmaları Merkezi, "Melâmiyye" maddesi, 29: 25-29.

TDV İslâm Ansiklopedisi (2004). Reşat Öngören, İstanbul: TDV İslâm Araştırmaları Merkezi, "Mevlânâ Celâleddîn-i Rûmî" maddesi, 29: 441-448.

TDV İslâm Ansiklopedisi (2004). Tahsin Yazıc1, İstanbul: TDV İslâm Araştırmaları Merkezi, "Menâkıbü'l-Ârifîn" maddesi, 29: 114-115

TDV İslâm Ansiklopedisi (2007). Cengiz Tomar, İstanbul: TDV İslâm Araştırmaları Merkezi, "Pazar" maddesi, 34: 203-206.

TDV İslâm Ansiklopedisi (2009). Osman Gazi Özgüdenli, İstanbul: TDV İslâm Araştırmaları Merkezi, "Selçuklular" maddesi, 36: 388-389.

TDV İslâm Ansiklopedisi (2013). Mustafa Tatçı, İstanbul: TDV İslâm Araştırmaları Merkezi, "Yûnus Emre" maddesi, 43: 600-606.

Ülgener, S.F. (2015) Zihniyet ve Din. Derin Yayınları.

Vorlander, K. (2008). Felsefe Tarihi. İz Yayıncılık.

Zeyrek, Y. (2015). Dede Korkut Kitabı. Ötüken Neşriyat. 